Review

\title{
Antibiotics in Food Chain: The Consequences for Antibiotic Resistance
}

\author{
Shashi B. Kumar, Shanvanth R. Arnipalli and Ouliana Ziouzenkova * \\ Department of Human Sciences, The Ohio State University, Columbus, OH 43210, USA; \\ kumar.864@osu.edu (S.B.K.); arnipalli.1@buckeyemail.osu.edu (S.R.A.) \\ * Correspondence: ziouzenkova.1@osu.edu
}

Received: 19 August 2020; Accepted: 8 October 2020; Published: 13 October 2020

\begin{abstract}
Antibiotics have been used as essential therapeutics for nearly 100 years and, increasingly, as a preventive agent in the agricultural and animal industry. Continuous use and misuse of antibiotics have provoked the development of antibiotic resistant bacteria that progressively increased mortality from multidrug-resistant bacterial infections, thereby posing a tremendous threat to public health. The goal of our review is to advance the understanding of mechanisms of dissemination and the development of antibiotic resistance genes in the context of nutrition and related clinical, agricultural, veterinary, and environmental settings. We conclude with an overview of alternative strategies, including probiotics, essential oils, vaccines, and antibodies, as primary or adjunct preventive antimicrobial measures or therapies against multidrug-resistant bacterial infections. The solution for antibiotic resistance will require comprehensive and incessant efforts of policymakers in agriculture along with the development of alternative therapeutics by experts in diverse fields of microbiology, biochemistry, clinical research, genetic, and computational engineering.
\end{abstract}

Keywords: microbiome; resistome; horizontal evolution; quorum-sensing

\section{Introduction and Background}

In 1928 Alexander Fleming serendipitously discovered penicillin [1] (Figure 1). Its utility as medicine became clear following the extraction of a small amount of penicillin from a fungus Penicillium chrysogenum, by Howard Florey and Ernst Chain in 1941, at the Radcliffe Infirmary. This extract was initially used for treating a policeman in Oxford, England who contracted a likely infection of Staphylococcus aureus with an admixture of various Streptococci. The condition of the policeman was initially improved; however, the amount and quality of penicillin synthesis were inadequate at the time. Eventually, sepsis relapsed and the policeman died. Presently, penicillin and other antibiotics are produced in copious amounts. The term antibiotic is defined as a natural or synthetic chemical inhibiting both the growth and survival of microorganisms. Among these antibiotics, methicillin is considered to be one of the most effective. However, studies revealed that sepsis cases increased from 621,000 to 1,141,000 between the years of 2000 and 2008 [2]. The death toll from sepsis rose from 154,000 to 207,000 cases. The extent of this rise is attributed to the emergence of methicillin resistant S. aureus (MRSA). MRSA marks the beginning of the development of antibiotic-resistant microbes (also called ESKAPE pathogens, standing for Enterococcus faecium, S. aureus, Klebsiella pneumoniae, Acinetobacter baumannii, Pseudomonas aeruginosa, and Enterobacteriaceae) [3]. It is reported that in the United States, India, Thailand, and European Union, antibiotic resistance causes more than 23,000, $58,000,38,000$ and 25,000 deaths per year, respectively [4-7]. The predicted deaths from drug-resistant microbial pathogens could rise from approximately 700,000 per year to 10 million deaths per year by 2050 and threaten global health [8]. 


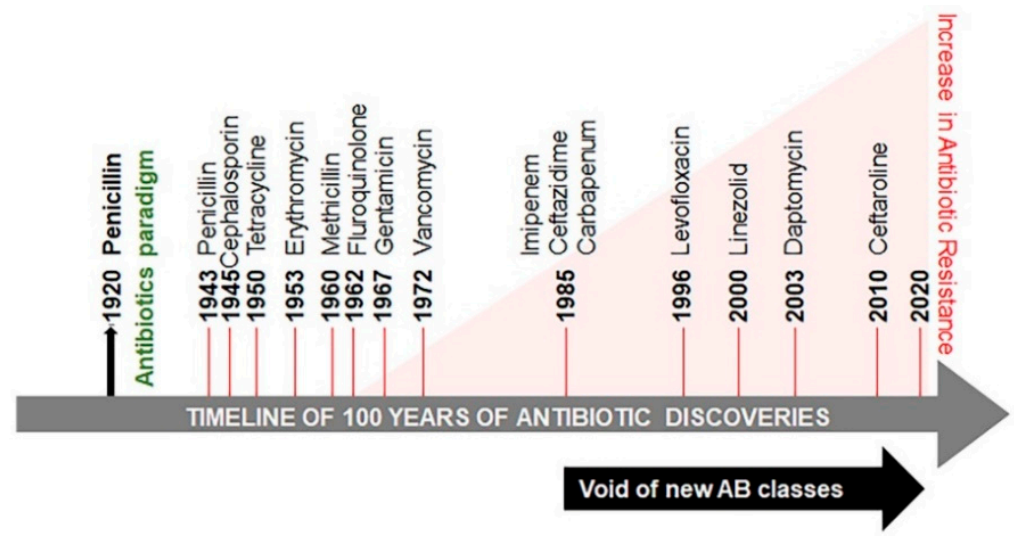

Figure 1. Timeline of antibiotic discovery and its onset of resistance. The antibiotic paradigm emerges out of the followed discovery of penicillin. Between the 1960s and the 1980s there was a surge in the discovery of antibiotics, but this development declined between the 1980s and the 1990s. The identification of new antibiotic classes by pharmaceutical companies has stagnated since 1987 and coincided with progressively increased antibiotic resistance and mortality related to antibiotic-resistant infections.

Microorganisms are able to develop antibiotic-resistant genes to enhance their survival, thus minimizing the treatment options for microbial infections and increasing mortality in human populations. Antibiotic resistance is classified into three categories based on the threat: urgent, serious, and concerning (Table 1). The global threat of resistance to imipenem antibiotics in A. baumannii infections has been reported in both Organization for Economic Co-operation and Development (OECD) and non-OECD countries across the globe [9]. Several reasons are responsible for the development of antibiotic resistance globally and in developing countries, such as India $[10,11]$. Poor public health conditions and health care systems, availability of antibiotics over the counter, lack of public knowledge of appropriate dosage of antibiotics and their haphazard use, as well as a high incidence of infectious diseases have been proposed as the major factors augmenting the problem. This continuum of antibiotic resistance concept was proposed to describe the progressive interconnecting influence of human, industrial, agricultural, and wild environments [12]. The crude mortality due to infectious diseases in India is 416.75 per 100,000 persons, which is twice the rate in the United States (roughly 200 per 100,000 persons) [13]. The problem is aggravated further by the void in the development of new classes of antibiotics since 1990 (Figure 1) [14-17].

Table 1. Classification of antibiotic resistance threats.

\begin{tabular}{lll}
\hline \multicolumn{1}{c}{ Urgent } & \multicolumn{1}{c}{ Serious } & \multicolumn{1}{c}{ Concerning } \\
\hline 1. A. baumannii, P. aeruginosa, & 1. Streptococcus pneumonia, penicillin-non-susceptible & \\
carbapenem-resistant & 2. Haemophilus influenzae, ampicillin-resistant & \\
2. Clostridium difficile (CDIFF) & 3. Shigella spp., fluoroquinolone-resistant & 1. Group B \\
3. N. gonorrhoeae-3rd generation & 4. Enterococcus spp., vancomycin resistant & Streptococcus (GBS), \\
cephalosporin-resistant, & 5. Multidrug-resistant Acinetobacter & clindamycin resistant \\
fluoroquinolone-resistant & 6. Drug resistant Campylobacter & 2. Group A \\
4. Carbapenem- and 3rd & 7.Extended-spectrum $\beta$-lactamase producing & Streptococcus (GAS), \\
generation cephalosporin & Enterobacteriae (ESBLs) & erythromycin resistant \\
resistant Enterobacteriaceae: & 8. Multidrug-resistant P. aeruginosa & 3. S. aureus, \\
K. pneumonia, E. coli, & 9. Drug-resistant non-typhoidal Salmonella & vancomycin resistant \\
Enterobacter spp., Serratia spp., & 10. Drug-resistant Salmonella serotype Typhi & \\
Proteus spp. and Providencia spp., & 11. Drug resistant M. tuberculosis & \\
Morganella spp. & 12. Methicillin-resistant S. aureus (MRSA) & \\
\hline
\end{tabular}

The advances in social and medical fields, including cancer therapy and organ transplantation, would not have been possible without effective antibiotic treatment to control bacterial infections. However, global antibiotic resistance is on the rise. In this review, we thoroughly apprise comprehensive 
evidence of various factors leading to the development of antibiotic resistance, followed by route of entry of drug-resistant pathogens into the food chain, and a plethora of alternative strategies to mitigate the menace of antibiotic resistance for a healthier future.

\section{Drug Resistance Continuum}

Microorganisms are evolving rapidly to endure and proliferate in unfavourable environments. Although antibiotic resistance appeared soon after clinical use of antibiotics, initially the problem was of low concern and was condoned (Figure 1) [18]. Sulphonamide-resistant Streptococcus pyogenes appeared in the human clinical settings in early 1930s, while penicillin-resistant S. pyogenes was noted in the 1940s. The problem of multidrug-resistant enteric bacteria became noticeable in the 1950s [19]. Antibiotic resistance develops as a result of vertical or horizontal evolution (Figure 2). Advantageous mutations cause antibiotic tolerance, which is transmitted to offspring (vertical evolution) or to another bacteria via conjugation, transduction, or transformation mode (horizontal evolution), that are then passed down to progeny (vertical evolution). The comprehensive genomic insights into human pathogens have shown that horizontal gene transfer is an important mechanism of antibiotic resistance gene (ARG) acquisition among microorganisms along with the vertical transfer [20]. A decade ago, an ARG, the New Delhi metallo- $\beta$-lactamase 1 (NDM-1) was identified in single isolates of K. pneumonia and Escherichia coli. Both were isolated from a patient first admitted to a hospital in New Delhi, India, and then repatriated to Sweden [21]. This was followed by the spread of antibiotic resistance in every geographical region [22,23]. NDM-1 has no detectable sequence homology with other classes of these genes, thus indicating their archaic origin [24,25]. Bacteria carrying extended spectrum $\beta$-lactamases (ESBL) impart resistance to penicillin and cephalosporins, extensively drug-resistant (XDR) Mycobacterium tuberculosis, and multi-drug resistant A. baumanni, Enterobacteriaceae, Neisseria gonorrhoea, and $P$. aeruginosa $[26,27]$.

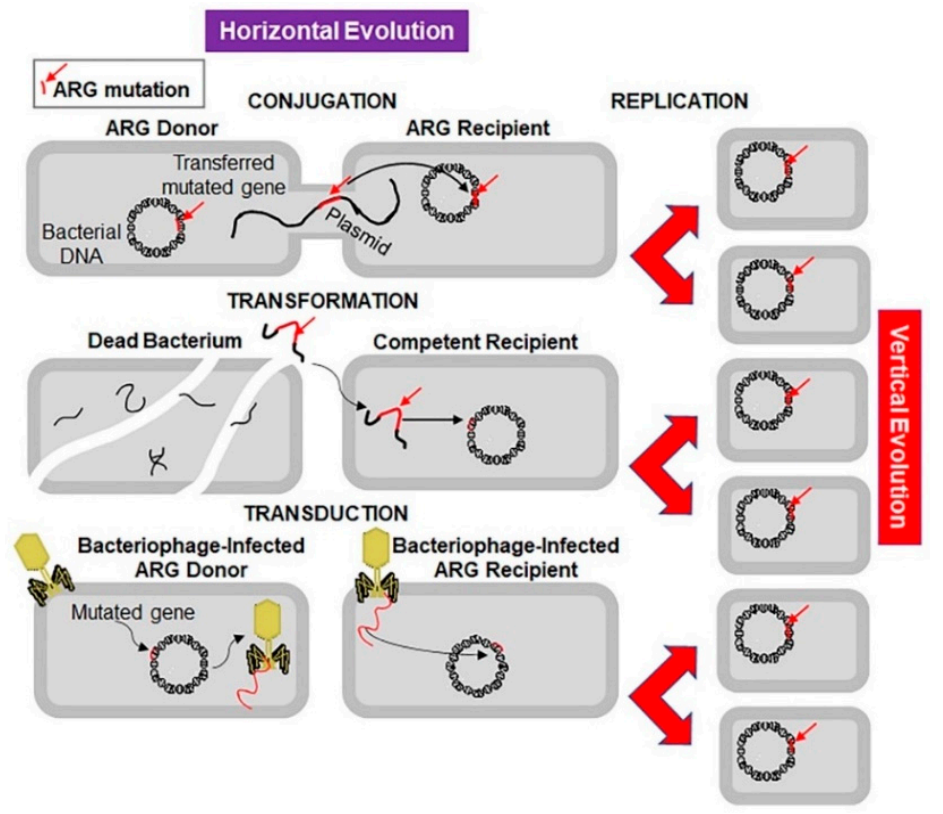

Figure 2. Mechanisms of horizontal and vertical transmission in bacteria for the development of antibiotic resistance. The left panel shows the horizontal transmission of an antibiotic resistant gene (ARG, red line indicated by a red arrow) by the three main mechanisms: conjugation, transformation, and transduction. Conjugation involves transfer of the ARG from a donor bacterium to a recipient by direct contact and plays a crucial role in dissemination of antibiotic resistance. Transformation involves uptake of the free DNA with the ARG from the environment. Transduction is a virus-mediated gene transfer by bacteriophages. The right panel shows the vertical evolution carried out by replication of bacteria containing the ARG. 


\section{The Detrimental Effects of Antibiotics Misuse}

The dogma that antibiotics are safe for humans has been dominant for many decades, and only recently has it started to be challenged. Antibiotics are recommended to humans based on rigorous clinical trials, examining antibiotics use against microorganisms, and their efficacy and safety. However, antibiotics can have serious side effects in human cells. The effects of antibiotics on pathways in humans are listed in Table 2 [28]. Some medical professionals and some regulatory agencies continue to underestimate the debilitating effects of antibiotics in humans. For instance, fluoroquinolones are routinely prescribed by medical doctors worldwide, even though they cause several side effects, encompassing damage to muscles, tendons, neuropsychiatric disorders, and mitochondrial toxicity. Given the repeated incidences of fluoroquinolone-associated disability (FQAD) and the lack of effective FQAD treatment, the drug should be used exclusively for serious infections [29]. The overwhelming potential side effects of antibiotics have triggered many scientific professionals and agencies to reassess the uses of antibiotics.

Table 2. Mechanism of action of antibiotics.

\begin{tabular}{ll}
\hline \multicolumn{1}{c}{ Mechanism of Action } & \multicolumn{1}{c}{ Name of Antibiotic Families } \\
\hline Inhibition of protein synthesis & $\begin{array}{l}\text { Tetracyclines, aminoglycosides, streptogramins, } \\
\text { ketolides, macrolides, lincosamides, daptomycin }\end{array}$ \\
\hline Inhibition of DNA synthesis & Fluoroquinolones, daptomycin \\
\hline Inhibition of RNA synthesis & Rifampin and other metronidazoles, daptomycin \\
\hline Inhibition of cell wall synthesis & $\begin{array}{l}\text { Penicillins, cephalosporins, carbapenems, monobactams, } \\
\text { glycopeptides }\end{array}$ \\
\hline Disrupt functions of bacterial outer membrane & Daptomycin, polymyxin B, colistin, and lipopetides \\
\hline Competitive inhibition of folic acid synthesis & Sulfonamides, trimethoprim \\
\hline
\end{tabular}

\section{Livestock as a Major Contributor of Antibiotic Resistance}

Animal livestock is an integral component of the global economy as a major contributor of food and materials, as well as draft power for transportation and agriculture operations in developing countries. To promote growth and weight gain, entire herds or flocks of farm animals are routinely fed with low dosages of antibiotics in their food or water. This practice is implemented to stave off disease in animals living in often crowded and unsanitary spaces. This activity leads to massive accumulation of antibiotics in the environment, and acquisition of antibiotic resistance in microorganisms coming in contact with an antibiotic [30] (Figure 3). Antibiotic consumption in the livestock sector is the highest in China (23\%), the US (13\%), Brazil $(9 \%)$, and India (3\%), accounting for the majority of worldwide sale of antibiotics [31-33]. The spread of antibiotic-resistant microorganisms to humans is carried through the consumption of contaminated food and drinks, direct contact with animals, or by environmental exposure, for example, through consumption of contaminated water (Figure 3). Both animal and human pathogens serve as donors of ARG to pathogens that infect humans. Table 3 summarizes major bacteria classes originating from animal species [34]. The use of fluoroquinolones (e.g., enrofloxacin) in food-producing animals has contributed to the spread of ciprofloxacin-resistant Salmonella, Campylobacter and E. coli, which are resistant to most therapies. A global trade with animal products contaminated with ARG affects the food supply in new regions. For instance, the use of a glycopeptide (avoparcin) as an antibiotic and a growth promoter in animals in Europe resulted in the expansion of vancomycin-resistant enterococci (VRE) in commensal microorganisms in livestock, on meat from these animals, and in the commensal flora of healthy humans worldwide [35]. 


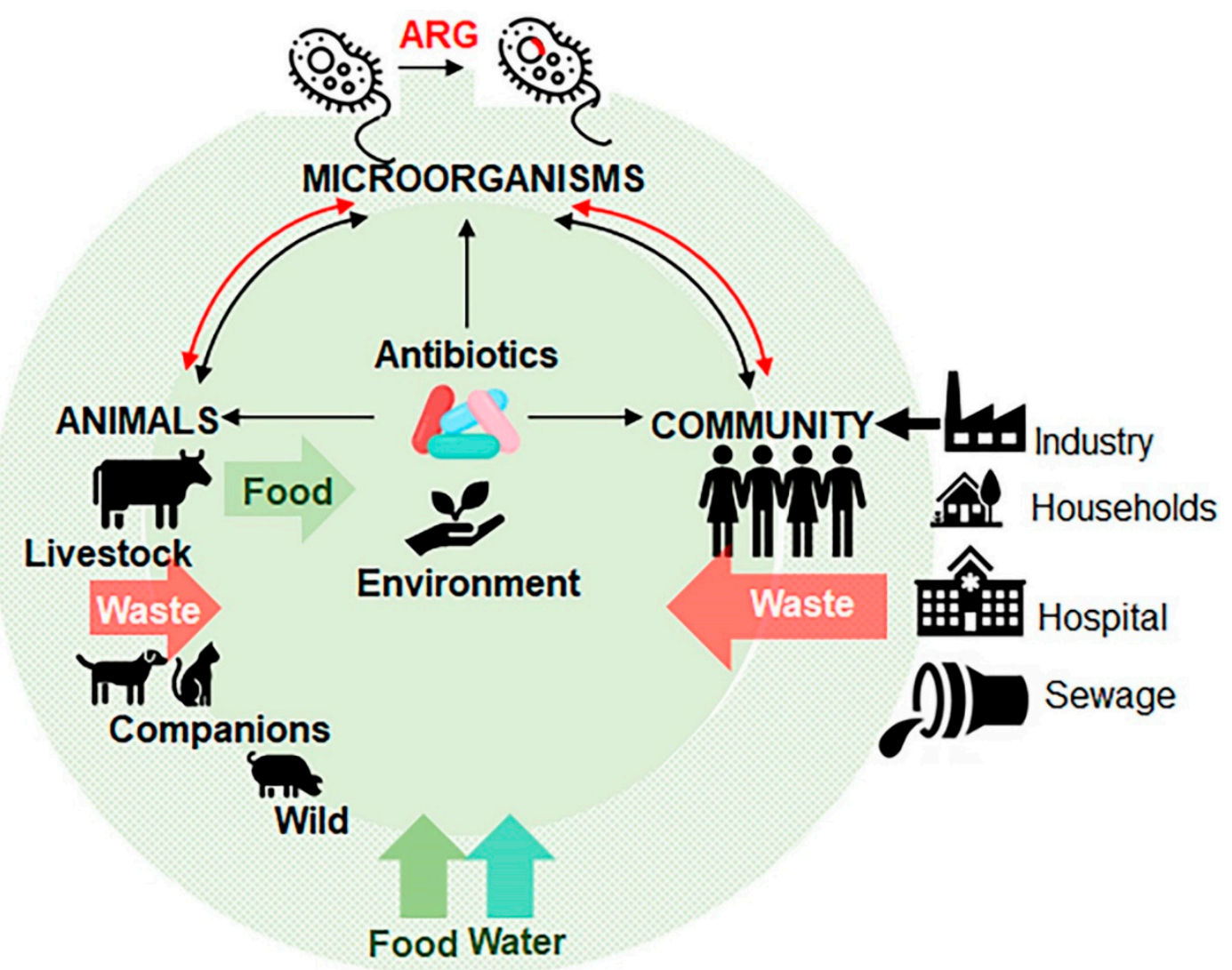

Figure 3. Schematics of the major route of antibiotic resistance genes (ARG, a red inserted line) dissemination in environment. The diagram indicates the contribution of human communities to the production of antibiotics and their uses in hospitals, farms, and households. Generated antibiotic waste is released onto sewage, hence contaminating water, soil, and environment. Bacteria develop ARG mutations as a result of such exposure to antibiotics in the environment, and in human and animal hosts. ARG-containing bacteria spread in humans and animals through direct infections, food, or environment. The arrows indicate the putative transmission paths of entry of antibiotics and ARG.

To decrease global antibiotic-resistant bacterial infections, some measures have been implemented with respect to the use of antibiotics for non-therapeutic purposes, such as antibiotic use in animals intended for food production [36]. The imposed ban on the use of avoparcin in animal feed in the European Union has reduced the incidences of VRE in animals and its occurrences in the general population [37]. The efficacy of these measures suggests that animal-derived ARG could be one of the major sources for development of antibiotic resistance. Substantial attention is focused on the understanding of molecular mechanisms involved in the human acquisition of ARG from the animals. The transfer of antibiotic resistance determinants from animal to human through horizontal gene transfer is extremely difficult to detect and quantify. It is thought to drive the evolution of metallo- $\beta$-lactamase, e.g., NDM- 1 , and perhaps the use of antibiotics in agriculture accelerated this process $[24,25,38]$. The ARG phenomenon greatly hinders the progress of agriculture. 
Table 3. ARG in animal production settings.

\begin{tabular}{|c|c|c|c|c|c|}
\hline S1. No. & Bacterial Species & Infection & $\begin{array}{c}\text { Antibiotic } \\
\text { Resistance Pattern }\end{array}$ & $\begin{array}{c}\text { Sources of Human } \\
\text { Infection }\end{array}$ & Genes \\
\hline 1 & Campylobacter spp. & $\begin{array}{l}\text { Gastrointestinal } \\
\text { sequelae: } \\
\text { Guillain-Barré } \\
\text { syndrome }\end{array}$ & $\begin{array}{l}\text { Fluoroquinolones, } \\
\text { erythromycin }\end{array}$ & $\begin{array}{l}\text { Food-producing animals } \\
\text { (poultry) }\end{array}$ & tet $O$, gyr $A[39,40]$ \\
\hline 2 & Enterococcus spp. & $\begin{array}{l}\text { Sepsis, urinary } \\
\text { tract }\end{array}$ & $\begin{array}{l}\text { Aminoglycosides } \\
\text { ampicillin } \\
\text { vancomycin }\end{array}$ & $\begin{array}{l}\text { Food-producing animals } \\
\text { (poultry); People } \\
\text { exposed to hospital care, } \\
\text { food animals }\end{array}$ & $\begin{array}{l}\text { Tuf, } \operatorname{VanC}-1, \\
\operatorname{VanC} C-2-\operatorname{Van} C-3, \\
\text { pbp5 [41-45] }\end{array}$ \\
\hline 3 & E. coli & $\begin{array}{l}\text { Gastrointestinal, } \\
\text { urinary tract, } \\
\text { diarrhoea }\end{array}$ & $\begin{array}{l}\text { Quinolones } \\
\text { sulphonamides } \\
\text { trimethoprim }\end{array}$ & Childcare facilities & $\begin{array}{l}\text { Bla, qnrS, frdD } \\
{[46-48]}\end{array}$ \\
\hline 4 & $\begin{array}{l}\text { Salmonella spp. } \\
\text { (non-typhoidal) }\end{array}$ & $\begin{array}{l}\text { Gastrointestinal, } \\
\text { diarrhoea }\end{array}$ & $\begin{array}{l}\text { Cephalosporins } \\
\text { quinolones } \\
\text { tetracyclines }\end{array}$ & $\begin{array}{l}\text { Food-producing animals } \\
\text { (pigs, cows, poultry) }\end{array}$ & IntI1, qnrA [49-52] \\
\hline 5 & S. pneumoniae & $\begin{array}{l}\text { Otitis media, } \\
\text { pneumonia, } \\
\text { sinusitis, } \\
\text { meningitis }\end{array}$ & $\begin{array}{l}\text { Penicillin, } \\
\text { macrolides, } \\
\text { cephalosporins, } \\
\text { tetracyclines }\end{array}$ & $\begin{array}{l}\text { Childcare facilities, } \\
\text { paediatric populations }\end{array}$ & $\operatorname{erm}(B), \operatorname{mef}[53-56]$ \\
\hline 6 & S. pyogenes & $\begin{array}{l}\text { Pharyngitis, } \\
\text { impetigo, cellulitis }\end{array}$ & $\begin{array}{l}\text { Macrolides, } \\
\text { tetracyclines }\end{array}$ & $\begin{array}{l}\text { Childcare facilities, } \\
\text { paediatric Populations, } \\
\text { schools }\end{array}$ & $\begin{array}{l}\text { ermB, ermA and } \\
\text { mefA [57] }\end{array}$ \\
\hline \multirow[t]{3}{*}{7} & S. aureus & & & & \\
\hline & $\begin{array}{l}\text { Community- } \\
\text { associated }\end{array}$ & $\begin{array}{l}\text { Skin, soft tissue, } \\
\text { pneumonia, sepsis }\end{array}$ & $\begin{array}{l}\text { Methicillin, } \\
\text { cephalosporins, } \\
\text { macrolides }\end{array}$ & $\begin{array}{l}\text { Childcare facilities, } \\
\text { injections, drug users }\end{array}$ & \multirow{2}{*}{$\begin{array}{l}\operatorname{erm}(A), \operatorname{erm}(C), \text { tetK, } \\
\text { tet } M, \text { aac } A-a p h D, \\
\operatorname{vat}(A), \operatorname{vat}(B) \text { and } \\
\operatorname{vat}(C)[58,59]\end{array}$} \\
\hline & $\begin{array}{l}\text { Healthcare- } \\
\text { associated }\end{array}$ & $\begin{array}{l}\text { Endocarditis, } \\
\text { pneumonia, sepsis }\end{array}$ & $\begin{array}{l}\text { Methicillin, } \\
\text { cephalosporins, } \\
\text { quinolones, } \\
\text { aminoglycosides, } \\
\text { macrolides }\end{array}$ & $\begin{array}{l}\text { People exposed to } \\
\text { healthcare facilities such } \\
\text { as nursing homes, } \\
\text { dialysis, recent surgery } \\
\text { or hospitalization }\end{array}$ & \\
\hline 8 & N. gonorrhoeae & $\begin{array}{l}\text { Urethritis, pelvic } \\
\text { inflammatory } \\
\text { disease }\end{array}$ & $\begin{array}{l}\text { Penicillin, } \\
\text { cephalosporins, } \\
\text { quinolones }\end{array}$ & Commercial sex workers & $\begin{array}{l}\text { penA, penB, NorM } \\
{[60,61]}\end{array}$ \\
\hline
\end{tabular}

\section{Scale of Antibiotic Use in Animals and Humans}

Global use of antimicrobial substances in animal production for food (milk, eggs, and meat) was estimated at 63,151 \pm 1560 tons (100\%) in 2010, with a projected increase to $105,596 \pm 3605$ tons $(167 \%)$ by 2030 . The additional $34 \%$ rise will depend on the implementation of intensive farming systems by 2030. A recent study provides a projection of antibiotic use for livestock in India, where quinolones are expected to increase up to $243 \%$ by 2030 , compared to their use in 2015 , while the use of ampicillin and co-trimoxazole has declined [62]. It is envisaged that by 2030, the consumption of antimicrobials in Asia could reach roughly 51,851 tons; representing $182 \%$ of the current global consumption of antimicrobials in animal food in 2010. An overall 176\% increase in antibiotic use was observed during the decade 2000-2010 in Brazil, Russia, India, China, and South Africa (BRICS) [63]. Animal consumption of antimicrobials in BRICS countries is expected to increase up to $199 \%$ by 2030 compared to current use. In human populations its expected growth will be around $113 \%$ during the same period [64]. India's consumption of $12.9 \times 10^{9}$ units of antibiotics (10.7 units/person) made it the largest consumer, followed by China, which used $10.0 \times 10^{9}$ units (7.5 units/person) in 2010. The United States used $6.8 \times 10^{9}$ units (22.0 units/person) of antibiotics during this time [32]. BRICS countries are five major rising national economies. From 2000 to 2010, antibiotic sales in the health care sector in India and China increased to $123 \%$ and $157 \%$ respectively [63]. This intensified antibiotics production significantly pollutes the environment. 


\section{Anthropogenic Contamination of Environment with Antibiotics and ARGs}

Antibiotics can enter the environment through different routes (Figure 3). Antibiotics produced by industry as well as their metabolites are released from plants, hospitals, farms, and households with biological wastes (urine, faeces, sputum, placenta, tissues and organs) or by means of abandoned animals (e.g., cattle in India), stray animals (dogs, pigs, and birds) and open human defecation in slum areas. From the sewage, waste water treatment plants (WWTPs), and surface run off the antibiotics and/or ARG contaminate water and can be dispersed on fields that directly or indirectly enter humans' and animals' food chain systems $[23,65,66]$. The resistant bacteria follow similar routes to invade human systems [67]. These routes result in an environment where antibiotics, ARGs, antibiotic resistant bacteria, and the environmental bacterial flora can interact. These types of environments become likely a hotspots for the development of new ARGs by horizontal gene transfer that cross-contaminate different animal species. Humans come in contact with resistant microorganisms through numerous routes including consumption of contaminated foods, interactions with animals, and within contaminated environments. Infected human hosts spread ARGs to microflora inhabiting the hosts [23] and within communities (Figure 3). For instance, the $\beta$-lactamase cblA present in Bacteroides is one of the most abundant ARGs in the microbiota of both healthy persons and patients [68,69]. The progress and challenges in the understanding of ARG in the microbiota have been described in numerous excellent reviews [70-74].

Metagenomics is a diagnostic tool for detection of pathogens outbreaks in the faecal samples and tracking ARG in individual patients, which is known as resistome profiling $[71,75,76]$. Future advances in genome sequencing technologies are likely to facilitate high-throughput characterization of the resistome by metagenomic sequencing of microbiome in patients and assessing the possibility for horizontal gene transfer.

\section{Alternative Strategies to Combat Antibiotic Resistance}

Alternative strategies are imperative to combat infectious pathogens containing ARG [14,77]. The emerging therapies, including bacteriophage therapy [78], predatory bacteria, immunotherapeutics, haemofiltration devices, quorum sensing inhibitors, antimicrobial adjuvants, faecal microbiota transplantation (FMT), nano-antibiotics and nitric oxide (NO)-releasing nanoparticles, antimicrobial peptides (AMPs) or bacteriocins $[15,79,80]$, essential oils, as well as competitive exclusion of pathogens through genetically modified probiotics and postbiotics, RNA therapy, and use of vaccines, are the prospective strategies discussed below.

\subsection{Phage or Bacteriophage Therapies}

Bacteriophages are viruses using bacteria as a host. They are extensively investigated as a replacement for antibiotics against drug-resistant pathogens despite numerous challenges [81-83]. Phage therapy was introduced in the early 1920s and in Georgia, Eastern Europe [84]. The technique is gaining popularity because phages are ubiquitous, harmless, and could be administered orally with food [84], topically on open wounds or surface infections [85], or intravenously during systemic infections (Table 4). The recent innovations in the gene therapies have created novel opportunities too for phage therapy to disrupt antibiotic resistance genes by Clustered Regularly Interspaced Short Palindromic Repeat (CRISPR) interaction with CRISPR-associated (Cas) (CRISPR/Cas) gene editing tool [86] or deliver antimicrobial proteins in recombinant phages [85]. However, the fine specificity of phage towards host bacterium species precludes their applications as an empiric therapy for acute infections. The phage libraries need a continuous update to ensure their efficacy against antibiotic resistant bacteria. Developing and establishing a complete library of phages for every plausible infectious bacterium is challenging [85]. 


\subsection{Predatory Bacteria}

Obligate predatory bacteria, including Bdellovibrio bacteriovorus and Micavibrio aeruginosavorus, populate soils and water globally [87]. Epibiotic or endobiotic predatory bacteria are attached to the membrane of the Gram-negative bacteria to consume prey contents and divide outside or inside their prey [88-90]. Several studies have demonstrated that B. bacteriovorus can kill more than 100 human bacterial pathogens acting as "living antibiotic" [91]. Predatory bacteria are free-living, are not pathogenic to humans, and have low immunogenicity. The use of $B$. bacteriovorus is being investigated as the novel therapeutic approach against antibiotic resistant and/or unidentified microbial infections. However, further research is required to understand the mechanism of predator-host interactions.

Table 4. Phage therapy in humans and in animal models.

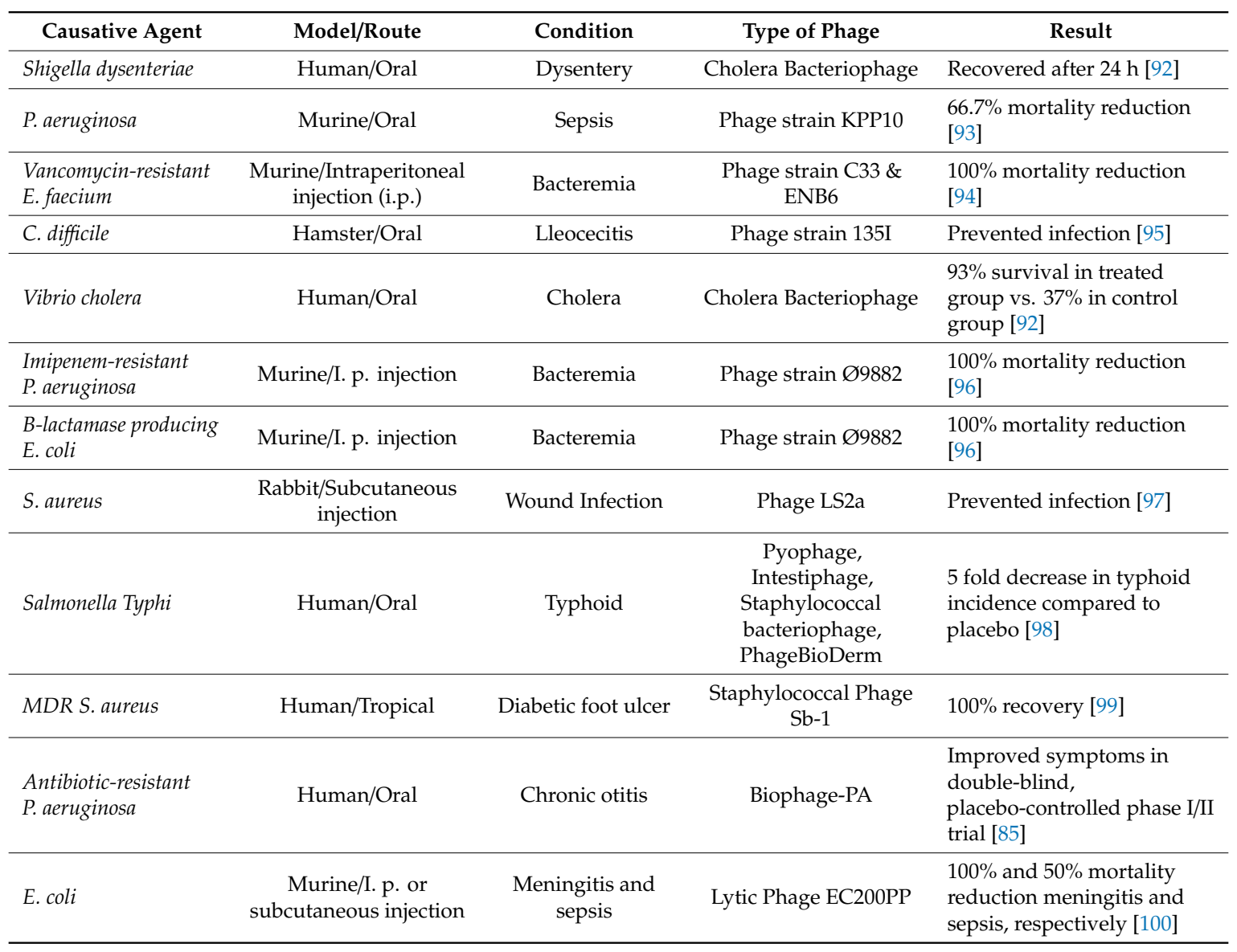

\subsection{Immunotherapeutics}

Immunotherapeutics are biomolecules that improve immune responses in the host against infectious agents. A large number of immune adjuvants such as cytokines interleukin-2 (IL-2), IFN-gamma, IL-7, IL-12, as well as granulocyte macrophage colony stimulating factor (GM-CSF) and programmed cell death ligand-1 antibody are under clinical investigation to improve hosts' immune defence in subjects with antibiotic resistance or immunocompromised patients [101,102]. For instance, G-CSF stimulates neutrophil production in patients with low neutrophil counts caused by chemotherapeutics. Pegfilgrastim is most widely used synthetic immunostimulant of G-CSF production [103]. In agriculture, a bovine G-CSF or its inducer pegbovigrastim are administered to cattle prior to parturition to boost the immune system and decrease the incidence of mastitis [104-106]. 
Monoclonal and polyclonal antibodies provide passive immunity against bacterial pathogens. The antibodies mAb F598, recognizing the major component of bacterial Gram-positive and Gram-negative cell wall poly N-acetylglucosamine (PNAG), are in a phase I clinical trial [107]. The two neutralizing, human monoclonal antibodies against $C$. difficile toxins A (CDA1) and $B$ (CDB1) reduced the recurrence of $C$. difficile infection in double-blind placebo randomized controlled studies [91,108]. Recently, human monoclonal antibody bezlotoxumab was approved by US Food and Drug Administration (FDA) for prevention of recurrent C. difficile infection [109]. The advantageous immune response against infections requires precise timing for intervention with immunotherapeutics that could limit its applications.

\subsection{Haemofiltration Devices}

Extracorporeal pathogen removal filters such as mannose binding lectins [110] or bound heparin [111] are being studied. These therapies can bind and remove an array of blood stream pathogens. These haemofilters will cause reduction in the bacterial load which allows the host to develop innate and adaptive immune responses against residual antibiotic-resistant pathogens.

\subsection{Quorum-Sensing Inhibitors}

Bacteria behave as single organisms at low densities in a favourable environment. However, they acquire multicellular type of communication at high density or in adverse, antimicrobial environments by signalling termed quorum sensing (QS). Bacterial QS molecules include:

(1) Oligopeptides (5-10 amino acid cyclic thiolactone), such as $\mathrm{N}$-acyl homoserine lactones used by Gram-negative bacteria [112,113],

(2) Furanosyl borate (Autoinducer-2, AI-2),

(3) N-acyl homoserine lactones (AHLs),

(4) Methyl-dodecanoic acid, and

(5) Hydroxyl-palmitic acid methylester [114,115].

In response to QS molecules, bacteria express numerous genes mediating bioluminescence, virulence, biofilm formation, sporulation, and other processes. Two widely studied QS molecules are AHL and peptides used by Gram-positive bacteria. The substances which inhibit the signal transduction and virulence activities of bacteria [116-118] are termed QS inhibitors, quorum quenchers, or antipathogenic signal interference. A recent study has identified 4-aminoquinolone as QS inhibitor in S. marcescens and P. auroginosa [119]. Recent studies have identified the range of new QS inhibitors derived from different sources, such as ajoene, iberin, sulforaphane, phenolics, O-glycosylated flavanones, polyphenols, urolithins, limonoids, caffeine, Chamaemelum nobile flower extract, leaves extract from Kalanchoe (Bryophyllum pinnatum), phytols, avellanin C, pigments (melanin, melanoid, pheomelanin), cyclic dipeptides, quercetin, engineered variant of hyper-thermostable lactonase SsoPox, thermostable lactonase, and colostrum hexasaccharide. These QS inhibitors have been used against human pathogens such as P. aeruginosa, Yersinia enterocolitica, Aeromonas hydrophila, S. aureus, Chromobacterum violaceum, A. baumannii, and E. coli [120]. QS inhibitor gallium effectively controls a biofilm formation via inhibition of iron metabolism [119,121-124]. The application of QS inhibitors for disruption of biofilms is being investigated for applications improving outcomes in systemic infections $[125,126]$.

\subsection{Antimicrobial Adjuvants (AA)}

AA modify the efficacy of existing antibiotics without changing theirintrinsic antimicrobial activity. AA reverse the bacterial mechanisms of antimicrobial resistance [127-129]. The antibiotic efficacy is modified by any of the following mechanisms [130-138]. 
(a) Biofilm disruption.

(b) Augmenting the uptake of antimicrobial in the target cell.

(c) Enhancing the oxidative stress in bacteria.

(d) Supressing the ARG.

(e) Inhibition of bacterial efflux pumps.

Different antimicrobial adjuvants classes such as efflux pump inhibitors (e.g., quinolines,), $\beta$-lactamase inhibitors (e.g., clavulanic acid), membrane permeabilizers (e.g., aminoglycosides), antivirulence compounds (e.g., OASS-inhibitors, SAT-inhibitors, Cys-inhibitors) have been used against Gram-negative and Gram-positive bacteria. The oral pharmaceutical Augmentin contains $\beta$-lactamase inhibitors clavulanic acid and amoxicillin. It effectively treats a wide range of bacterial infections, including bronchitis and Lyme disease [139]. Recent study has demonstrated that efflux pump inhibitors, including N-acetylcysteine, Tris-EDTA, and disodium EDTA have intrinsic antimicrobial activity and overcome antibiotic resistance. These AA could be used to enhance the efficacy of existing antibiotics against Gram-negative and multidrug-resistant bacteria $[140,141]$. Thus, AA provide an economical alternative to time-consuming and costly development of new antibiotics targeting antibiotic resistance.

\subsection{Faecal Microbiota Transplantation (FMT)}

FMT is also known as faecal bacteriotherapy, faecal transfusion, faecal transplant, faecal enema, human probiotic infusion (HPI) and stool transplant. FMT is the process of transplantation of bacterial solution from faecal matter of a healthy individual donor into a recipient's intestinal tract for total restoration of gut microbial flora using various methods including enema, nasogastric, nasoduodenal and colonoscopic routes (Figure 4) [142,143]. In veterinary medicine, it is known as "transfaunation" treatment for ruminate animals [144]. FMT was first introduced by Ben Eiseman and colleagues in 1958 for the treatment of four patients with pseudomembranous colitis [145], although the use of faecal enema therapy was described by Ge Hong in fourth-century China [146]. Few studies have shown that FMT is an effective treatment for people with $C$. difficile infection along with other gastrointestinal diseases, such as irritable bowel syndrome (IBS), colitis, constipation, diarrhoea, several neurological conditions such as Parkinson's and multiple sclerosis [147]. FMT is successfully used in clinical practice for treatment of recurrent $C$. difficile infection that cannot be cured with antibiotics. Currently, different microbiota-based products for other diseases are under development and/or in clinical trials [148]. Ethical issues appear to be another hindrance despite FMT safety and efficacy. Further research is needed to advocate for efficacy of FMT therapy against global antibiotic resistance menace. 


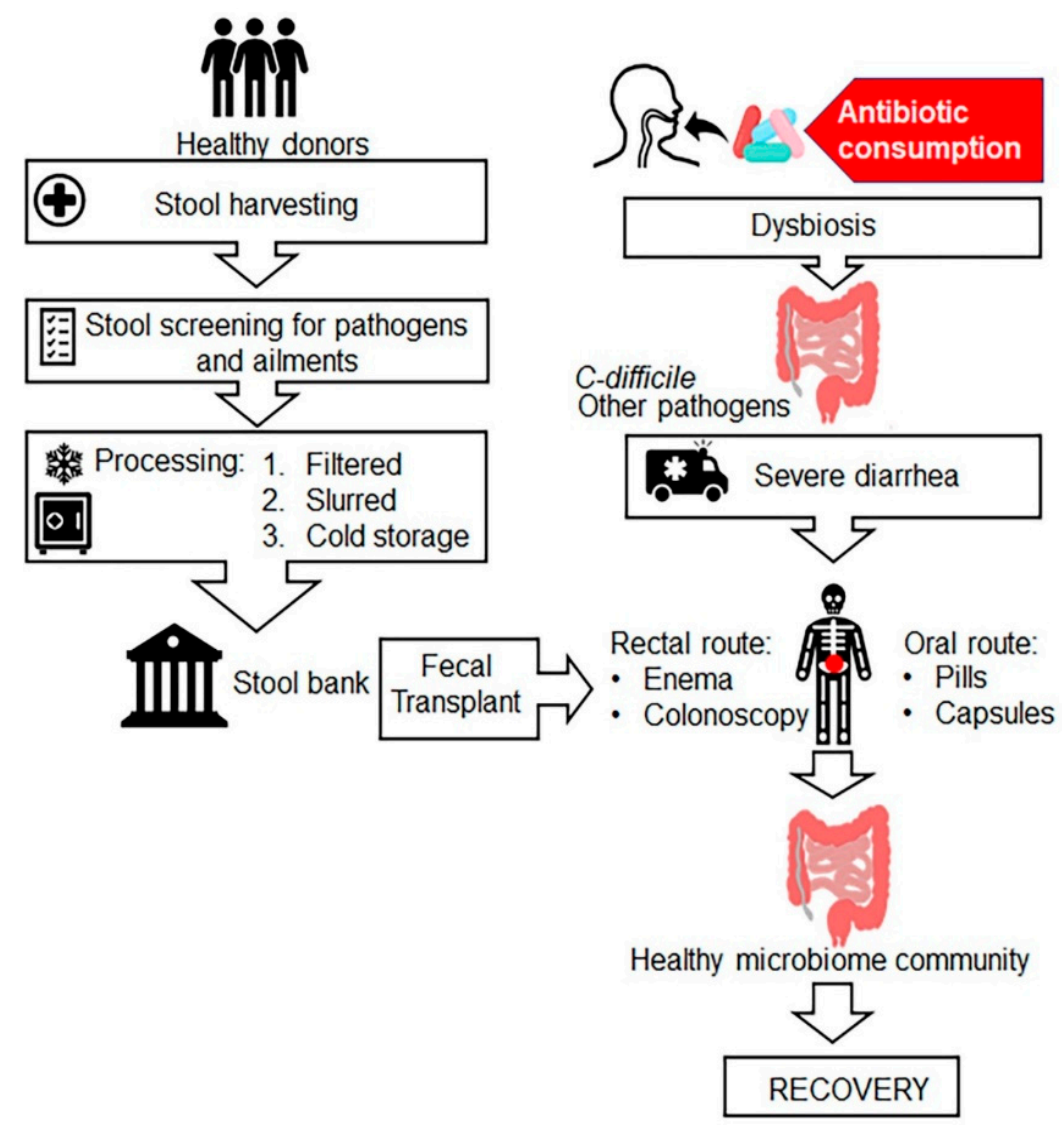

Figure 4. Schematic illustration of faecal microbiota transplantation (FMT) procedure. The left panel of the above figure depicts sample preparation where stool is harvested from healthy donors, processed via different stages such filtration, slurry preparation followed by cold storage in stool bank. The right panel illustrates the FMT procedure, where processed faecal microbiota of healthy donor stored in stool bank is either delivered via rectal route or oral route to the diseased patients (recipient) to provide a healthy microbiome community.

\subsection{Nanoantibiotics}

Although bacteria develop resistance to 'free' antibiotics, such as amphotericin B, oxacillin, cloxacillin, amoxicillin, cephalexin, cefotaxime, ceftazidime, vancomycin, streptomycin, and erythromycin, the coating of antibiotics on metal nanoparticles show enhanced antibacterial, antiviral, and anticancer efficacy (Table 5). Various research groups have demonstrated antimicrobial efficacy of silver $(\mathrm{Ag})$ [149], copper $(\mathrm{Cu})$ [150], gold $(\mathrm{Au})$ [151], titanium (Ti) [152] and metal oxide-based nanoparticles such as titanium dioxide $\left(\mathrm{TiO}_{2}\right)$ [153], copper oxide (CuO) [154], zinc oxide ( $\mathrm{ZnO})$ [155], manganese oxide $\left(\mathrm{MnO}_{2}\right)$, aluminium oxide $\left(\mathrm{Al}_{2} \mathrm{O}_{3}\right)$ [156] with and without antibiotics. Nanoantibiotics are regarded as promising therapeutic candidates for future applications to combat antibiotic resistance in biomedical sciences (Figure 5) [157,158].

Nitric oxide (NO) is a potent agent against a wide range of Gram-positive and Gram-negative bacteria. NO is endogenously produced by oxidation of L-arginine to L-citrulline by NO synthase enzymes in eukaryotic cells [159-161]. Administration of exogenous NO donors or NO-releasing nanomaterial releases high concentrations of small gaseous molecules that permeate membranes (Figure 5). In bacteria, NO leads to the production of harmful ROS and reactive nitrogen species (RNS), such as peroxynitrite, dinitrogen trioxide $\left(\mathrm{N}_{2} \mathrm{O}_{3}\right)$, and nitrogen dioxide $\left(\mathrm{NO}_{2}\right)$, by mechanisms involving inhibition of catalase activity [162]. Both ROS and RNS are also produced in host macrophages and other immune cells pathways to destroy the microorganisms [163,164]. A study had reported that NO-releasing nanomaterials decreased the biofilm-infected wounds that promoted wound closure [165]. 
Thus, NO donor nanomaterial represents a new promising strategy to combat antibiotic resistance in the future.

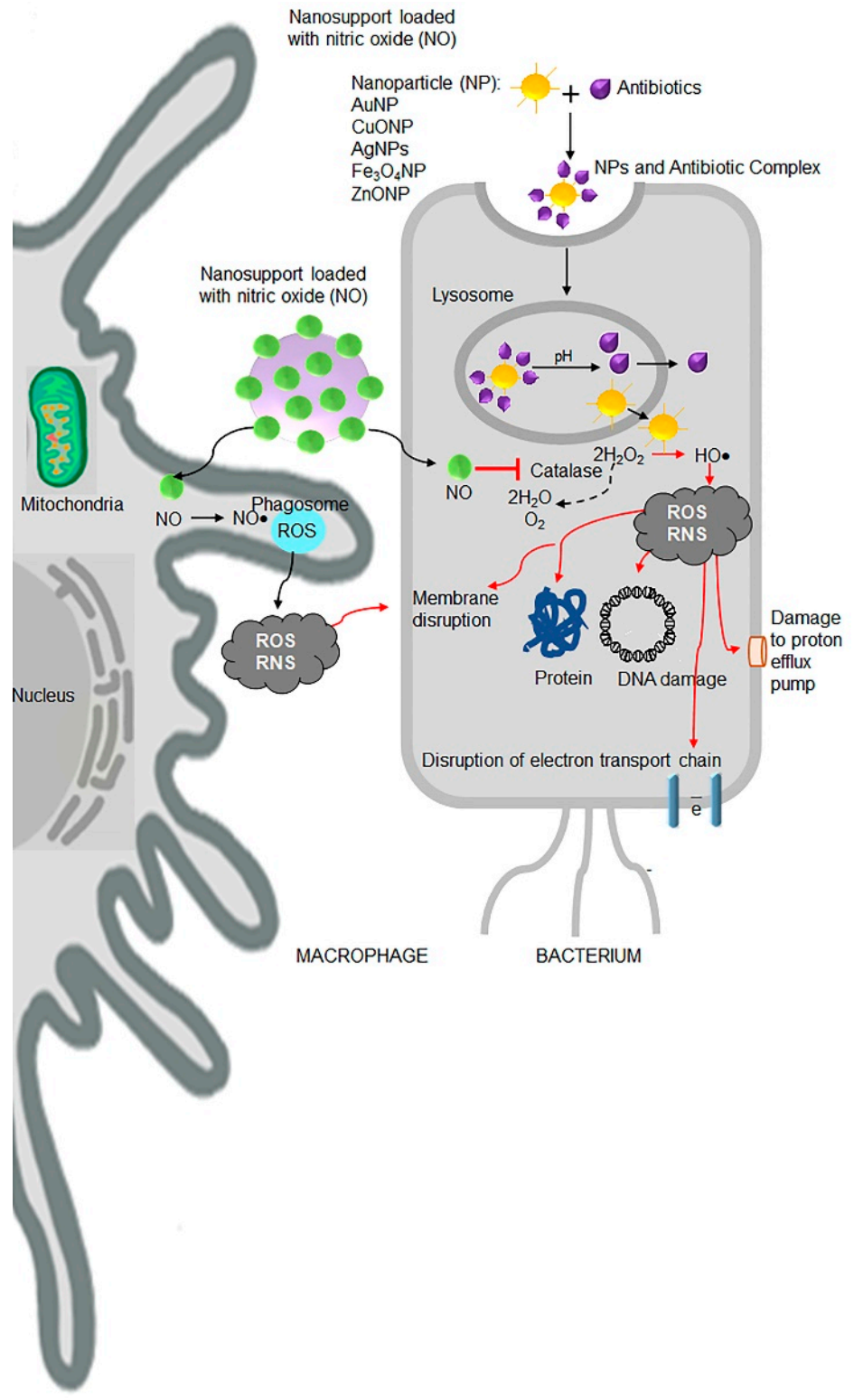

Figure 5. Schematic principle of action by nano-antibiotic therapies including nitric oxide (NO) releasing nanoparticles and nanoparticles in combination with antibiotics. The various nano-antibiotics (nAbts, purple shape) and NO-releasing nanoparticles (green circles) act via two components: metal ions $\left(\mathrm{Ag}^{+}, \mathrm{Cu}^{2+}, \mathrm{Zn}^{2+}\right.$ ) (yellow particle in the centre) and a releasing component such as NO with or without antibiotics. Both components increase production of reactive oxygen species (ROS) in the bacterium as well as in the host immune cells (e.g., macrophages, neutrophils). Left panel, in the bacterium, NO inhibits catalase activity, which leads to rise in levels of hydrogen peroxide. In the presence of transition metals of nanoparticles catalyse conversions of hydrogen peroxide to a hydroxyl radical $(\mathrm{HO} \bullet)$. Hydroxyl radical is one of many ROS and RNS responsible for oxidative and nitrosative stress and death of bacteria. ROS leads to disruption of cell membrane, interruption of transmembrane electron transport, oxidation of cellular components, protein and DNA damage. These actions disrupt structural and functional integrity of bacteria. 
Table 5. Effect of metal/metal oxide nanoparticles with or without antibiotics against various bacteria.

\begin{tabular}{|c|c|c|}
\hline S.No. & Metal Nanoparticles Used & Action against Bacteria \\
\hline 1 & Silver & $\begin{array}{l}\text { E. coli, M. tuberculosis, MRSA, S. aureus, S. pyogens, } \\
\text { K. pneumonia, [166-175]. }\end{array}$ \\
\hline 2 & Titanium & $\begin{array}{l}\text { K. pneumonia, S. aureus, A. baumannii, E. coli, } \\
\text { Morganella morganii [152] }\end{array}$ \\
\hline 3 & Gold & $\begin{array}{l}\text { MRSA, E. coli, P. aeruginosa, S. aureus, } \\
\text { Enterococcus spp., B. subtilis }[151,176,177]\end{array}$ \\
\hline S.No. & Metal Oxide Nanoparticles Used & Action against Bacteria \\
\hline 1 & Zinc oxide & MRSA, Streptococcus agalactiae [155] \\
\hline 2 & Manganese oxide & MRSA [178] \\
\hline 3 & Manganese oxide & E. coli $[156]$ \\
\hline S.No. & $\begin{array}{l}\text { Metal and Metal Oxide Nanoparticle } \\
\text { Composite Used }\end{array}$ & Action against Bacteria \\
\hline 1 & Zinc doped copper oxide nanocomposite & MRSA, E. coli [154] \\
\hline 2 & Copper doped zinc oxide nanocomposite & E. coli, S. aureus [179] \\
\hline S.No. & $\begin{array}{l}\text { Metal Oxide Nanoparticles in Combination } \\
\text { with Antibiotics Used }\end{array}$ & Action against Bacteria \\
\hline 1 & $\begin{array}{l}\mathrm{ZnO} \text { and Antibiotics (cefotaxime, ampicillin, } \\
\text { ceftriaxone, and cefepime) }\end{array}$ & $\begin{array}{l}\text { E. coli, K. pneumoniae, Sphingomonas paucimobilis, } \\
\text { and P. aeruginosa, respectively [180] }\end{array}$ \\
\hline 2 & $\begin{array}{l}\mathrm{TiO}_{2} \text { nanoparticles in combination with } \\
\text { antibiotics ( } \beta \text {-lactams, cephalosporin, } \\
\text { glycopeptides, aminoglycosides, } \\
\text { flouroquinolones, azlides, macrolides, } \\
\text { lincosamides, and sulphonamides) }\end{array}$ & Showed improved antibacterial activity [181] \\
\hline S.No. & $\begin{array}{l}\text { Metal Nanoparticles in Combination with } \\
\text { Antibiotics }\end{array}$ & Action against Bacteria \\
\hline 1 & Gold nanoparticles and Ampicillin & MDR P. aeruginosa, E. aerogenes, and MRSA [182] \\
\hline 2 & $\begin{array}{l}\text { AgNPs with ciprofloxacin, imipenem, } \\
\text { gentamycin, trimethoprim, and vancomycin }\end{array}$ & $\begin{array}{l}\text { MDR E. coli, P. aeruginosa, E. faecalis, S. aureus, } \\
\text { Micrococcus luteus, A. baumannii, K. pneumoniae, } \\
\text { and Bacillus spp. [183] }\end{array}$ \\
\hline
\end{tabular}

\subsection{Plant-Derived Antimicrobials and Essential Oils}

Historically, plant extracts have been used as an antibiotic in food preservatives. Plant-derived antimicrobials such as nerolidol, apritone, and bisabolol exert antimicrobial action combating Gram-positive and Gram-negative bacteria [184-186]. Moreover, no side effects and antimicrobial resistance toward these plant-derived phytochemicals have been documented thus far, probably, due to their multiple mechanisms of action. Essential oils are another type of secondary metabolites of aromatic plants. Liquid and volatile essential oils have significant medicinal properties in infectious and non-infectious diseases (Table 6) and have a low risk of antibiotic resistance [187,188]. Multiple studies, reviewed in [189], have revealed potent activity of essential oils from Eucalyptus camaldulensis against Gram-positive and Gram-negative bacteria. The complex composition of different essential oils and their specificity against different types of bacteria are now subject of intense investigation [190]. Pharmaceutical development use antimicrobials produced in flora, fauna, and microorganisms living in various ecological niches, including deep oceans, rain forests, and soils [191-194]. Potential use of natural antimicrobial metabolites is a promising strategy for controlling antibiotic resistance development in microorganisms in the future. 


\subsection{Probiotics, Postbiotics and Synbiotics}

Probiotics are the alive microorganisms or microbial feed supplements. They primarily comprise two classes of lactic acid-producing microorganisms: the bifidobacteria, and lactic acid bacteria (LAB). These microorganisms include species of Enterococus, Lactobacillus, Lactococcus, Pediococcus, Vogococcus, Aerococcus, Carnobaterium, Streprotococcus and Weisella. Most LAB, due to their safe (GRAS) status, and the abundance of some genera in the GI tract, mammary gland and female genitourinary tract, are regarded as alternative health-promoting treatments [195]. Postbiotics are functional bioactive compounds such as short-chain fatty acids, teichoic acid and other fermentation products. Identification of novel animal origin probiotics, postbiotics, and the non-viable microbial probiotics or probiotic metabolites that have biologic activities in host [196-199] may facilitate the development of alternative therapeutic combinations. These adjuvants can improve dosing regimens of traditional antibiotics and lessen the burden of enteric infections and side effects of antibiotic therapies.

Table 6. Effect of essential oils against bacteria.

\begin{tabular}{|c|c|c|}
\hline S.No. & Essential Oils (Components) & Active against Bacteria \\
\hline 1 & $\begin{array}{l}\text { Mentha (menthol, isomenthone, limonene, } \\
\text { iso-menthanol, menthol acetate, carvone, } \\
\beta \text {-pinene, } \alpha \text {-pinene, } 1,8 \text {-cineole, } \alpha \text {-terpineol, } \\
\text { isopulegol, pulegone, piperiton, piperitone oxide, } \\
\text { and } \beta \text {-phellandrene.) }\end{array}$ & $\begin{array}{l}\text { S. aureus, Staphylococcus epidermidis, B. cereus, } \\
\text { and E. coli, S. pyogenes, P. aeruginosa, } \\
\text { Pseudomonas fluorescens, C. albicans, and V. } \\
\text { cholerae, [200-202] }\end{array}$ \\
\hline 2 & $\begin{array}{l}\text { Basil (Linalool, epi- } \alpha \text {-cadinol, } \alpha \text {-bergamotene, } \\
\gamma \text {-cadinene, germacrene D, camphor. } \\
\text { methylchavikol, methylcinnamat, linolen, } \\
\text { eugenol, cis-geraniol, } 1,8 \text {-cineole, } \alpha \text {-bergamotene, } \\
\beta \text {-caryophyllene, viridiflorol.) }\end{array}$ & $\begin{array}{l}\text { S. aureus and B. subtilis, Staphylococcus, } \\
\text { Pseudomonas, and Enterococcus genera, L. } \\
\text { monocytogenes and B. cereus Vibrio spp. and } \\
\text { Aerobacter hydrophila [203-205] }\end{array}$ \\
\hline 3 & $\begin{array}{l}\text { Oregano (thymol, carvacrol, } \rho \text {-cymene, } \\
\text { thymoquinone, and } \gamma \text {-terpinene.) }\end{array}$ & $\begin{array}{l}\text { Sarcina lutea, S. aureus, C. albicans, E. faecalis, } \\
\text { and B. cereus }[206,207]\end{array}$ \\
\hline 4 & $\begin{array}{l}\text { Rosemary ( } \alpha \text {-pinene, myrcene, } 1,8 \text {-cineole, } \\
\text { camphor, camphene, } \alpha \text {-terpineol, and borneol.) }\end{array}$ & $\begin{array}{l}\text { S. epidermidis, S. aureus, B. subtilis, Proteus } \\
\text { vulgaris, P. aeruginosa, and E. coli. [208-211] }\end{array}$ \\
\hline
\end{tabular}

\subsection{RNA Therapy}

The bacterial small (50-500 nucleotides) regulatory RNAs (sRNAs) participate in many events such as growth, virulence onset, biofilm formation, stress response and antibiotic resistance. Modulation of bacterial sRNAs function by specific drugs could enhance the efficacy of antibiotics [91]. Acquired bacterial immunity based on CRISPR/Cas interaction has been used to target extended spectrum beta-lactams, carbapenems, or colistin resistance genes without changes in the host microbiota [212].

These RNA-based therapies, such as sRNAs and RNA-guided CRISPR/Cas technologies holds promise for successful delivery of highly effective RNA elements into the bacteria to fight against antibiotic resistance.

\subsection{Development and Use of Vaccines}

Vaccines provide possible solutions for the emerging antimicrobial resistance (AMR) crisis. Vaccines continue to be one of the most effective interventions against primary and secondary antibiotic resistant bacterial infections. Several candidate vaccines against the most common bacteria, e.g., C. difficile (Phase III), M. tuberculosis (Phase II), Group B Streptococcus (Phase II), S. aureus (Phase II), are in mid-stage clinical development by major pharma companies [213]. 


\section{Mitigation Steps to Curb the Menace of Antibiotic Resistance}

Tackling antibiotic resistance with preventive protective measures and policies in combination with effective medicines is a high priority to ensure prevention and treatment of infectious diseases [214,215]. The following measures have been proposed:

- Strengthening of surveillance data.

- Improving awareness of antibiotic resistance.

- Improving the practices of antibiotic prescription.

- Improvement of poor sanitation, malnutrition, and endemic infections.

- Optimizing the use of antimicrobial medicines and restricting over the counter sale of antibiotics.

- Improving the public awareness and government commitment.

- Reducing the incidence of infection by various means.

- Reducing clinical trial risk.

- Boosting market value for not feeding animals antibiotics.

- Strengthening the regulation of farm feeding of antibiotics.

- Ensuring the quality of generic antibiotics.

- Early sharing of data.

- Organizing world antibiotic awareness week.

- Implementation of the global antimicrobial resistance surveillance system (GLASS).

- Establishing the global antibiotic research and development partnership (GARDP).

- Establishing the interagency coordination group on antimicrobial resistance (IACG).

\section{Future Strategies, Challenges, and Outlooks}

The biggest imminent threat caused by the spreading of antibiotic resistance is the rise of multi-drug resistant bacteria such as MRSA, VRE, and ESBL. Bacteria develop resistance to drugs by various resistance development routes, including the major spreading routes among bacteria by 'Jumping DNA' termed transposons. Barabas's group have proposed a therapeutic new target, a transposase protein that blocks the transposon insertion mechanism between the bacteria and interrupts transfer of ARG [216]. Another promising innovation is an early detection technique for antibiotic resistance using a $\mathrm{CeO}_{2}$ nanoparticle biosensor. The search for better treatment strategies for antibiotic resistance is continuing. Combined chemical and biological approaches would contribute to the development of a new potent remedies to mitigate this immense threat.

The microbial infections posing threats to human and animal health with major antibiotic resistant pathogens challenging agricultural food supply and the integrity of the environment. While some examples of ARG dissemination between environmental and pathogenic bacteria are evident, the intricate mechanisms were described in a scarce number of studies remain incomplete Antibiotics became a part of modern medicine around seven decades ago, and their efficacy and safety do not meet the demands of the intensifying animal production and growing population facing global treat of infectious diseases. Experts from diverse fields such as clinical research, microbiology, genetic and computational engineering, imaging and modelling should work jointly to evolve strategies and develop novel therapeutics to address this problem.

Author Contributions: S.B.K. wrote MS, developed figures and tables, S.R.A. developed figures and edited MS, O.Z. revised and edited figures and MS. All authors have read and agreed to the published version of the manuscript.

Funding: The project was supported by NIH, the National Center for Research Resources UL1RR025755 and NCI P30CA16058 (OSUCCC), the NIH Roadmap for Medical Research. The content is solely the responsibility of the authors and does not necessarily represent the official views of the National Center for Research Resources or the National Institutes of Health. This work was supported by the Falk Trust Award. S.B.K. work was supported by Long Term ICMR-DHR International Fellowship for Young Bio-medical Scientists 2019-20, office order No. INDO/FRC/452 (Y-60)/2019-20-IHD. 
Conflicts of Interest: The authors declare no conflict of interest.

\section{References}

1. Tan, S.Y.; Tatsumura, Y. Alexander Fleming (1881-1955): Discoverer of penicillin. Singap. Med. J. 2015, 56, 366-367. [CrossRef]

2. Hayden, G.E.; Tuuri, R.E.; Scott, R.; Losek, J.D.; Blackshaw, A.M.; Schoenling, A.J.; Nietert, P.J.; Hall, G.A. Triage sepsis alert and sepsis protocol lower times to fluids and antibiotics in the ED. Am. J. Emerg. Med. 2016, 34, 1-9. [CrossRef]

3. Boucher, H.W.; Talbot, G.H.; Bradley, J.S.; Edwards, J.E.; Gilbert, D.; Rice, L.B.; Scheld, M.; Spellberg, B.; Bartlett, J. Bad bugs, no drugs: No ESKAPE! An update from the Infectious Diseases Society of America. Clin. Infect. Dis. 2009, 48, 1-12. [CrossRef]

4. Laxminarayan, R.; Duse, A.; Wattal, C.; Zaidi, A.K.; Wertheim, H.F.; Sumpradit, N.; Vlieghe, E.; Hara, G.L.; Gould, I.M.; Goossens, H.; et al. Antibiotic resistance-the need for global solutions. Lancet Infect. Dis. 2013, 13, 1057-1098. [CrossRef]

5. The Bacterial Challenge: Time to React; ECDC/EMEA Joint Technical Report; European Medicines Agency and European center for Disease Control: Stockholm, Sweden, 2009. [CrossRef]

6. Holmberg, S.D.; Solomon, S.L.; Blake, P.A. Health and economic impacts of antimicrobial resistance in Thailand. J. Health Serv. Res. Policy 2012, 6, 352-360.

7. Available online: https://www.cdc.gov/drugresistance/ (accessed on 1 August 2020).

8. de Kraker, M.E.; Stewardson, A.J.; Harbarth, S. Will 10 Million People Die a Year due to Antimicrobial Resistance by 2050? PLoS Med. 2016, 13, e1002184. [CrossRef]

9. Xie, R.; Zhang, X.D.; Zhao, Q.; Peng, B.; Zheng, J. Analysis of global prevalence of antibiotic resistance in Acinetobacter baumannii infections disclosed a faster increase in OECD countries. Emerg. Microbes Infect. 2018, 7, 31. [CrossRef]

10. Laxminarayan, R.; Chaudhury, R.R. Antibiotic Resistance in India: Drivers and Opportunities for Action. PLoS Med. 2016, 13, e1001974. [CrossRef]

11. Ganguly, N.K.; Arora, N.K.; Chandy, S.J.; Fairoze, M.N.; Gill, J.P.; Gupta, U.; Hossain, S.; Joglekar, S.; Joshi, P.C.; Kakkar, M.; et al. Rationalizing antibiotic use to limit antibiotic resistance in India. Indian J. Med. Res. 2011, 134, 281-294.

12. Zaheer, R.; Cook, S.R.; Barbieri, R.; Goji, N.; Cameron, A.; Petkau, A.; Polo, R.O.; Tymensen, L.; Stamm, C.; Song, J.; et al. Surveillance of Enterococcus spp. reveals distinct species and antimicrobial resistance diversity across a One-Health continuum. Sci. Rep. 2020, 10, 3937. [CrossRef]

13. Armstrong, G.L.; Conn, L.A.; Pinner, R.W. Trends in infectious disease mortality in the United States during the 20th century. JAMA 1999, 281, 61-66. [CrossRef]

14. Kumar, M.; Yadav, A.K.; Verma, V.; Singh, B.; Mal, G.; Nagpal, R.; Hemalatha, R. Bioengineered probiotics as a new hope for health and diseases: An overview of potential and prospects. Future Microbiol. 2016, 11, 585-600. [CrossRef] [PubMed]

15. Nordmann, P.; Dortet, L.; Poirel, L. Carbapenem resistance in Enterobacteriaceae: Here is the storm! Trends Mol. Med. 2012, 18, 263-272. [CrossRef] [PubMed]

16. Singh, R.K.; Chang, H.W.; Yan, D.; Lee, K.M.; Ucmak, D.; Wong, K.; Abrouk, M.; Farahnik, B.; Nakamura, M.; Zhu, T.H.; et al. Influence of diet on the gut microbiome and implications for human health. J. Transl. Med. 2017, 15, 73. [CrossRef] [PubMed]

17. Zaman, S.B.; Hussain, M.A.; Nye, R.; Mehta, V.; Mamun, K.T.; Hossain, N. A Review on Antibiotic Resistance: Alarm Bells are Ringing. Cureus 2017, 9, e1403. [CrossRef] [PubMed]

18. Davies, J.; Davies, D. Origins and evolution of antibiotic resistance. Microbiol. Mol. Biol. Rev. 2010, 74, 417-433. [CrossRef]

19. Levy, S.B.; Marshall, B. Antibacterial resistance worldwide: Causes, challenges and responses. Nat. Med. 2004, 10, S122-S129. [CrossRef]

20. Sommer, M.O.A.; Munck, C.; Toft-Kehler, R.V.; Andersson, D.I. Prediction of antibiotic resistance: Time for a new preclinical paradigm? Nat. Rev. Microbiol. 2017, 15, 689-696. [CrossRef] 
21. Yong, D.; Toleman, M.A.; Giske, C.G.; Cho, H.S.; Sundman, K.; Lee, K.; Walsh, T.R. Characterization of a new metallo-beta-lactamase gene, bla(NDM-1), and a novel erythromycin esterase gene carried on a unique genetic structure in Klebsiella pneumoniae sequence type 14 from India. Antimicrob. Agents Chemother. 2009, 53, 5046-5054. [CrossRef]

22. Planta, M.B. The role of poverty in antimicrobial resistance. J. Am. Board Fam. Med. 2007, 20, 533-539. [CrossRef]

23. Wellington, E.M.; Boxall, A.B.; Cross, P.; Feil, E.J.; Gaze, W.H.; Hawkey, P.M.; Johnson-Rollings, A.S.; Jones, D.L.; Lee, N.M.; Otten, W.; et al. The role of the natural environment in the emergence of antibiotic resistance in gram-negative bacteria. Lancet Infect. Dis. 2013, 13, 155-165. [CrossRef]

24. Hall, B.G.; Salipante, S.J.; Barlow, M. Independent origins of subgroup B1 + B2 and subgroup B3 metallo-beta-lactamases. J. Mol. Evol. 2004, 59, 133-141. [CrossRef] [PubMed]

25. Bebrone, C. Metallo-beta-lactamases (classification, activity, genetic organization, structure, zinc coordination) and their superfamily. Biochem. Pharmacol. 2007, 74, 1686-1701. [CrossRef]

26. Wright, G.D. Q\&A: Antibiotic resistance: Where does it come from and what can we do about it? BMC Biol. 2010, 8, 123. [CrossRef]

27. Wright, G.D. Antibiotic resistance in the environment: A link to the clinic? Curr. Opin. Microbiol. 2010, 13, 589-594. [CrossRef] [PubMed]

28. Kapoor, G.; Saigal, S.; Elongavan, A. Action and resistance mechanisms of antibiotics: A guide for clinicians. J. Anaesthesiol. Clin. Pharmacol. 2017, 33, 300-305. [CrossRef]

29. Marchant, J. When antibiotics turn toxic. Nature 2018, 555, 431-433. [CrossRef]

30. Allen, H.K. Antibiotic resistance gene discovery in food-producing animals. Curr. Opin. Microbiol. 2014, 19, 25-29. [CrossRef]

31. Kakkar, M.; Walia, K.; Vong, S.; Chatterjee, P.; Sharma, A. Antibiotic resistance and its containment in India. BMJ 2017, 358, j2687. [CrossRef]

32. Van Boeckel, T.P.; Brower, C.; Gilbert, M.; Grenfell, B.T.; Levin, S.A.; Robinson, T.P.; Teillant, A.; Laxminarayan, R. Global trends in antimicrobial use in food animals. Proc. Natl. Acad. Sci. USA 2015, 112, 5649-5654. [CrossRef]

33. Food and Drug Administration (FDA). Antimicrobials Sold or Distributed for Use in Food-Producing Animals; US Food and Drug Administration: Silver Spring, MD, USA, 2015.

34. Furuya, E.Y.; Lowy, F.D. Antimicrobial-resistant bacteria in the community setting. Nat. Rev. Microbiol. 2006, 4, 36-45. [CrossRef] [PubMed]

35. Marshall, B.M.; Levy, S.B. Food animals and antimicrobials: Impacts on human health. Clin. Microbiol. Rev. 2011, 24, 718-733. [CrossRef]

36. General Accounting Office (US). Antibiotic Resistance: Federal Agencies Need to Better Focus Efforts to Address Risk to Humans from Antibiotic Use in Animals. Report to Congressional Requesters. April 2004. Available online: http://www.gao.gov/new.items/d04490.pdf (accessed on 1 August 2020).

37. Hawkey, P.M. The growing burden of antimicrobial resistance. J. Antimicrob. Chemother. 2008, 62 (Suppl. s1), i1-i9. [CrossRef]

38. Martínez, J.L. Natural antibiotic resistance and contamination by antibiotic resistance determinants: The two ages in the evolution of resistance to antimicrobials. Front. Microbiol. 2012, 3, 1. [CrossRef] [PubMed]

39. Iovine, N.M. Resistance mechanisms in Campylobacter jejuni. Virulence 2013, 4, 230-240. [CrossRef] [PubMed]

40. Smith, K.E.; Besser, J.M.; Hedberg, C.W.; Leano, F.T.; Bender, J.B.; Wicklund, J.H.; Johnson, B.P.; Moore, K.A.; Osterholm, M.T. Quinolone-resistant Campylobacter jejuni infections in Minnesota, 1992-1998. Investigation Team. N. Engl. J. Med. 1999, 340, 1525-1532. [CrossRef]

41. Bates, J.; Jordens, J.Z.; Griffiths, D.T. Farm animals as a putative reservoir for vancomycin-resistant enterococcal infection in man. J. Antimicrob. Chemother. 1994, 34, 507-514. [CrossRef]

42. Miller, W.R.; Munita, J.M.; Arias, C.A. Mechanisms of antibiotic resistance in enterococci. Expert Rev. Anti-Infect. Ther. 2014, 12, 1221-1236. [CrossRef]

43. Morris, J.G., Jr.; Shay, D.K.; Hebden, J.N.; McCarter, R.J., Jr.; Perdue, B.E.; Jarvis, W.; Johnson, J.A.; Dowling, T.C.; Polish, L.B.; Schwalbe, R.S. Enterococci resistant to multiple antimicrobial agents, including vancomycin. Establishment of endemicity in a university medical center. Ann. Intern. Med. 1995, 123, 250-259. [CrossRef] 
44. Pillay, S.; Zishiri, O.T.; Adeleke, M.A. Prevalence of virulence genes in Enterococcus species isolated from companion animals and livestock. Onderstepoort J. Vet. Res. 2018, 85, e1-e8. [CrossRef]

45. Clark, N.C.; Teixeira, L.M.; Facklam, R.R.; Tenover, F.C. Detection and differentiation of vanC-1, vanC-2, and vanC-3 glycopeptide resistance genes in enterococci. J. Clin. Microbiol. 1998, 36, 2294-2297. [CrossRef] [PubMed]

46. Sáenz, Y.; Briñas, L.; Domínguez, E.; Ruiz, J.; Zarazaga, M.; Vila, J.; Torres, C. Mechanisms of resistance in multiple-antibiotic-resistant Escherichia coli strains of human, animal, and food origins. Antimicrob. Agents Chemother. 2004, 48, 3996-4001. [CrossRef] [PubMed]

47. Li, M.; Liu, Q.; Teng, Y.; Ou, L.; Xi, Y.; Chen, S.; Duan, G. The resistance mechanism of Escherichia coli induced by ampicillin in laboratory. Infect. Drug Resist. 2019, 12, 2853-2863. [CrossRef] [PubMed]

48. Fornasini, M.; Reves, R.R.; Murray, B.E.; Morrow, A.L.; Pickering, L.K. Trimethoprim-resistant Escherichia coli in households of children attending day care centers. J. Infect. Dis. 1992, 166, 326-330. [CrossRef]

49. Gunell, M.; Webber, M.A.; Kotilainen, P.; Lilly, A.J.; Caddick, J.M.; Jalava, J.; Huovinen, P.; Siitonen, A.; Hakanen, A.J.; Piddock, L.J. Mechanisms of resistance in nontyphoidal Salmonella enterica strains exhibiting a nonclassical quinolone resistance phenotype. Antimicrob. Agents Chemother. 2009, 53, 3832-3836. [CrossRef]

50. Alam, S.B.; Mahmud, M.; Akter, R.; Hasan, M.; Sobur, A.; Nazir, K.N.H.; Noreddin, A.; Rahman, T.; El Zowalaty, M.E.; Rahman, M. Molecular Detection of Multidrug Resistant Salmonella Species Isolated from Broiler Farm in Bangladesh. Pathogens 2020, 9, 201. [CrossRef]

51. Mølbak, K.; Gerner-Smidt, P.; Wegener, H.C. Increasing quinolone resistance in Salmonella enterica serotype Enteritidis. Emerg. Infect. Dis. 2002, 8, 514-515. [CrossRef]

52. Chiu, C.H.; Wu, T.L.; Su, L.H.; Chu, C.; Chia, J.H.; Kuo, A.J.; Chien, M.S.; Lin, T.Y. The emergence in Taiwan of fluoroquinolone resistance in Salmonella enterica serotype choleraesuis. N. Engl. J. Med. 2002, 346, 413-419. [CrossRef]

53. Kresken, M.; Henrichfreise, B.; Bagel, S.; Brauers, J.; Wiedemann, B. High prevalence of the ermB gene among erythromycin-resistant streptococcus pneumoniae isolates in Germany during the winter of 2000-2001 and in vitro activity of telithromycin. Antimicrob. Agents Chemother. 2004, 48, 3193-3195. [CrossRef]

54. Cherazard, R.; Epstein, M.; Doan, T.L.; Salim, T.; Bharti, S.; Smith, M.A. Antimicrobial Resistant Streptococcus pneumoniae: Prevalence, Mechanisms, and Clinical Implications. Am. J. Ther. 2017, 24, e361-e369. [CrossRef]

55. Jacobs, M.R.; Bajaksouzian, S.; Zilles, A.; Lin, G.; Pankuch, G.A.; Appelbaum, P.C. Susceptibilities of Streptococcus pneumoniae and Haemophilus influenzae to 10 oral antimicrobial agents based on pharmacodynamic parameters: 1997 U.S. Surveillance study. Antimicrob. Agents Chemother. 1999, 43, 1901-1908. [CrossRef] [PubMed]

56. Neto, A.S.; Lavado, P.; Flores, P.; Dias, R.; Pessanha, M.A.; Sousa, E.; Palminha, J.M.; Caniça, M.; Esperança-Pina, J. Risk factors for the nasopharyngeal carriage of respiratory pathogens by Portuguese children: Phenotype and antimicrobial susceptibility of Haemophilus influenzae and Streptococcus pneumoniae. Microb. Drug Resist. 2003, 9, 99-108. [CrossRef] [PubMed]

57. Bingen, E.; Bidet, P.; Mihaila-Amrouche, L.; Doit, C.; Forcet, S.; Brahimi, N.; Bouvet, A.; Cohen, R. Emergence of macrolide-resistant Streptococcus pyogenes strains in French children. Antimicrob. Agents Chemother. 2004, 48, 3559-3562. [CrossRef] [PubMed]

58. Strommenger, B.; Kettlitz, C.; Werner, G.; Witte, W. Multiplex PCR assay for simultaneous detection of nine clinically relevant antibiotic resistance genes in Staphylococcus aureus. J. Clin. Microbiol. 2003, 41, 4089-4094. [CrossRef]

59. Adwan, G.; Adwan, K.; Jarrar, N.; Amleh, A. Molecular detection of nine antibiotic resistance genes in methicillin resistant Staphylococcus aureus isolates. Roum. Arch. Microbiol. Immunol. 2014, 73, 9-17.

60. Demczuk, W.; Sidhu, S.; Unemo, M.; Whiley, D.M.; Allen, V.G.; Dillon, J.R.; Cole, M.; Seah, C.; Trembizki, E.; Trees, D.L.; et al. Neisseria gonorrhoeae Sequence Typing for Antimicrobial Resistance, a Novel Antimicrobial Resistance Multilocus Typing Scheme for Tracking Global Dissemination of N. gonorrhoeae Strains. J. Clin. Microbiol. 2017, 55, 1454-1468. [CrossRef]

61. Bhuiyan, B.U.; Rahman, M.; Miah, M.R.; Nahar, S.; Islam, N.; Ahmed, M.; Rahman, K.M.; Albert, M.J. Antimicrobial susceptibilities and plasmid contents of Neisseria gonorrhoeae isolates from commercial sex workers in Dhaka, Bangladesh: Emergence of high-level resistance to ciprofloxacin. J. Clin. Microbiol. 1999, 37, 1130-1136. [CrossRef] 
62. Laxminarayan, R.; Matsoso, P.; Pant, S.; Brower, C.; Røttingen, J.A.; Klugman, K.; Davies, S. Access to effective antimicrobials: A worldwide challenge. Lancet 2016, 387, 168-175. [CrossRef]

63. Van Boeckel, T.P.; Glennon, E.E.; Chen, D.; Gilbert, M.; Robinson, T.P.; Grenfell, B.T.; Levin, S.A.; Bonhoeffer, S.; Laxminarayan, R. Reducing antimicrobial use in food animals. Science 2017, 357, 1350-1352. [CrossRef] [PubMed]

64. World Bank. Available online: www.worldbank.org (accessed on 10 March 2015).

65. Scholz, M.; Lee, B.-H. Constructed wetlands: A review. Int. J. Environ. Stud. 2005, 62, 421-447. [CrossRef]

66. Hughes, S.R.; Kay, P.; Brown, L.E. Global synthesis and critical evaluation of pharmaceutical data sets collected from river systems. Environ. Sci. Technol. 2013, 47, 661-677. [CrossRef] [PubMed]

67. Baquero, F.; Martínez, J.L.; Cantón, R. Antibiotics and antibiotic resistance in water environments. Curr. Opin. Biotechnol. 2008, 19, 260-265. [CrossRef]

68. Forslund, K.; Sunagawa, S.; Kultima, J.R.; Mende, D.R.; Arumugam, M.; Typas, A.; Bork, P. Country-specific antibiotic use practices impact the human gut resistome. Genome Res. 2013, 23, 1163-1169. [CrossRef]

69. Hu, Y.; Yang, X.; Qin, J.; Lu, N.; Cheng, G.; Wu, N.; Pan, Y.; Li, J.; Zhu, L.; Wang, X.; et al. Metagenome-wide analysis of antibiotic resistance genes in a large cohort of human gut microbiota. Nat. Commun. 2013, 4, 2151. [CrossRef]

70. Sommer, M.O.A.; Dantas, G.; Church, G.M. Functional characterization of the antibiotic resistance reservoir in the human microflora. Science 2009, 325, 1128-1131. [CrossRef] [PubMed]

71. Buelow, E.; Gonzalez, T.B.; Versluis, D.; Oostdijk, E.A.; Ogilvie, L.A.; van Mourik, M.S.; Oosterink, E.; van Passel, M.W.; Smidt, H.; D'Andrea, M.M.; et al. Effects of selective digestive decontamination (SDD) on the gut resistome. J. Antimicrob. Chemother. 2014, 69, 2215-2223. [CrossRef] [PubMed]

72. Salyers, A.A.; Gupta, A.; Wang, Y. Human intestinal bacteria as reservoirs for antibiotic resistance genes. Trends Microbiol. 2004, 12, 412-416. [CrossRef] [PubMed]

73. Guiney, D.G., Jr.; Davis, C.E. Identification of a conjugative R plasmid in Bacteroides ochraceus capable of transfer to Escherichia coli. Nature 1978, 274, 181-182. [CrossRef] [PubMed]

74. Privitera, G.; Dublanchet, A.; Sebald, M. Transfer of multiple antibiotic resistance between subspecies of Bacteroides fragilis. J. Infect. Dis. 1979, 139, 97-101. [CrossRef]

75. Lanza, V.F.; Baquero, F.; Martínez, J.L.; Ramos-Ruíz, R.; González-Zorn, B.; Andremont, A.; Sánchez-Valenzuela, A.; Ehrlich, S.D.; Kennedy, S.; Ruppé, E.; et al. In-depth resistome analysis by targeted metagenomics. Microbiome 2018, 6, 11. [CrossRef]

76. Loman, N.J.; Constantinidou, C.; Christner, M.; Rohde, H.; Chan, J.Z.; Quick, J.; Weir, J.C.; Quince, C.; Smith, G.P.; Betley, J.R.; et al. A culture-independent sequence-based metagenomics approach to the investigation of an outbreak of Shiga-toxigenic Escherichia coli O104:H4. JAMA 2013, 309, 1502-1510. [CrossRef] [PubMed]

77. Kumar S, S.B. An Overview of Mechanisms and Emergence of Antimicrobials Drug Resistance. Adv. Anim. Vet. Sci. 2013, 1, 7-14.

78. Chan, B.K.; Abedon, S.T.; Loc-Carrillo, C. Phage cocktails and the future of phage therapy. Future Microbiol. 2013, 8, 769-783. [CrossRef] [PubMed]

79. Cotter, P.D.; Ross, R.P.; Hill, C. Bacteriocins-A viable alternative to antibiotics? Nat. Rev. Microbiol. 2013, 11, 95-105. [CrossRef] [PubMed]

80. Garcia-Gutierrez, E.; Mayer, M.J.; Cotter, P.D.; Narbad, A. Gut microbiota as a source of novel antimicrobials. Gut Microbes 2019, 10,1-21. [CrossRef]

81. Kadouri, D.E.; To, K.; Shanks, R.M.; Doi, Y. Predatory bacteria: A potential ally against multidrug-resistant Gram-negative pathogens. PLoS ONE 2013, 8, e63397. [CrossRef]

82. Shatzkes, K.; Connell, N.D.; Kadouri, D.E. Predatory bacteria: A new therapeutic approach for a post-antibiotic era. Future Microbiol. 2017, 12, 469-472. [CrossRef]

83. Shatzkes, K.; Tang, C.; Singleton, E.; Shukla, S.; Zuena, M.; Gupta, S.; Dharani, S.; Rinaggio, J.; Connell, N.D.; Kadouri, D.E. Effect of predatory bacteria on the gut bacterial microbiota in rats. Sci. Rep. 2017, 7, 43483. [CrossRef]

84. Wittebole, X.; De Roock, S.; Opal, S.M. A historical overview of bacteriophage therapy as an alternative to antibiotics for the treatment of bacterial pathogens. Virulence 2014, 5, 226-235. [CrossRef] 
85. Wright, A.; Hawkins, C.H.; Anggård, E.E.; Harper, D.R. A controlled clinical trial of a therapeutic bacteriophage preparation in chronic otitis due to antibiotic-resistant Pseudomonas aeruginosa; a preliminary report of efficacy. Clin. Otolaryngol. 2009, 34, 349-357. [CrossRef]

86. Yosef, I.; Manor, M.; Kiro, R.; Qimron, U. Temperate and lytic bacteriophages programmed to sensitize and kill antibiotic-resistant bacteria. Proc. Natl. Acad. Sci. USA 2015, 112, 7267-7272. [CrossRef] [PubMed]

87. Shatzkes, K.; Singleton, E.; Tang, C.; Zuena, M.; Shukla, S.; Gupta, S.; Dharani, S.; Onyile, O.; Rinaggio, J.; Connell, N.D.; et al. Predatory Bacteria Attenuate Klebsiella pneumoniae Burden in Rat Lungs. mBio 2016, 7. [CrossRef] [PubMed]

88. Findlay, J.S.; Flick-Smith, H.C.; Keyser, E.; Cooper, I.A.; Williamson, E.D.; Oyston, P.C.F. Predatory bacteria can protect SKH-1 mice from a lethal plague challenge. Sci. Rep. 2019, 9, 7225. [CrossRef] [PubMed]

89. Marine, E.; Milner, D.S.; Lambert, C.; Sockett, R.E.; Pos, K.M. A novel method to determine antibiotic sensitivity in Bdellovibrio bacteriovorus reveals a DHFR-dependent natural trimethoprim resistance. Sci. Rep. 2020, 10, 5315. [CrossRef]

90. Madhusoodanan, J. Inner Workings: Probing predatory bacteria as an antibacterial remedy. Proc. Natl. Acad. Sci. USA 2019, 116, 22887-22890. [CrossRef]

91. Cattoir, V.; Felden, B. Future Antibacterial Strategies: From Basic Concepts to Clinical Challenges. J. Infect Dis. 2019, 220, 350-360. [CrossRef]

92. Chanishvili, N. Phage therapy-History from Twort and d'Herelle through Soviet experience to current approaches. Adv. Virus Res. 2012, 83, 3-40. [CrossRef]

93. Watanabe, R.; Matsumoto, T.; Sano, G.; Ishii, Y.; Tateda, K.; Sumiyama, Y.; Uchiyama, J.; Sakurai, S.; Matsuzaki, S.; Imai, S.; et al. Efficacy of bacteriophage therapy against gut-derived sepsis caused by Pseudomonas aeruginosa in mice. Antimicrob. Agents Chemother. 2007, 51, 446-452. [CrossRef]

94. Biswas, B.; Adhya, S.; Washart, P.; Paul, B.; Trostel, A.N.; Powell, B.; Carlton, R.; Merril, C.R. Bacteriophage therapy rescues mice bacteremic from a clinical isolate of vancomycin-resistant Enterococcus faecium. Infect. Immun. 2002, 70, 204-210. [CrossRef]

95. Ramesh, V.; Fralick, J.A.; Rolfe, R.D. Prevention of Clostridium difficile-induced ileocecitis with Bacteriophage. Anaerobe 1999, 5, 69-78. [CrossRef]

96. Wang, J.; Hu, B.; Xu, M.; Yan, Q.; Liu, S.; Zhu, X.; Sun, Z.; Tao, D.; Ding, L.; Reed, E.; et al. Therapeutic effectiveness of bacteriophages in the rescue of mice with extended spectrum beta-lactamase-producing Escherichia coli bacteremia. Int. J. Mol. Med. 2006, 17, 347-355. [PubMed]

97. Wills, Q.F.; Kerrigan, C.; Soothill, J.S. Experimental bacteriophage protection against Staphylococcus aureus abscesses in a rabbit model. Antimicrob. Agents Chemother. 2005, 49, 1220-1221. [CrossRef] [PubMed]

98. Kutateladze, M.; Adamia, R. Phage therapy experience at the Eliava Institute. Med. Mal. Infect. 2008, 38, 426-430. [CrossRef] [PubMed]

99. Fish, R.; Kutter, E.; Wheat, G.; Blasdel, B.; Kutateladze, M.; Kuhl, S. Bacteriophage treatment of intransigent diabetic toe ulcers: A case series. J. Wound Care 2016, 25. [CrossRef]

100. Pouillot, F.; Chomton, M.; Blois, H.; Courroux, C.; Noelig, J.; Bidet, P.; Bingen, E.; Bonacorsi, S. Efficacy of bacteriophage therapy in experimental sepsis and meningitis caused by a clone O25b:H4-ST131 Escherichia coli strain producing CTX-M-15. Antimicrob. Agents Chemother. 2012, 56, 3568-3575. [CrossRef] [PubMed]

101. Opal, S.M. Non-antibiotic treatments for bacterial diseases in an era of progressive antibiotic resistance. Crit. Care 2016, 20, 397. [CrossRef] [PubMed]

102. Holland, S.M. Cytokine therapy of mycobacterial infections. Adv. Intern. Med. 2000, 45, 431-452.

103. Bonanno, G.; Procoli, A.; Mariotti, A.; Corallo, M.; Perillo, A.; Danese, S.; De Cristofaro, R.; Scambia, G.; Rutella, S. Effects of pegylated G-CSF on immune cell number and function in patients with gynecological malignancies. J. Transl. Med. 2010, 8, 114. [CrossRef]

104. Molineux, G. The design and development of pegfilgrastim (PEG-rmetHuG-CSF, Neulasta). Curr. Pharm. Des. 2004, 10, 1235-1244. [CrossRef]

105. Canning, P.; Hassfurther, R.; TerHune, T.; Rogers, K.; Abbott, S.; Kolb, D. Efficacy and clinical safety of pegbovigrastim for preventing naturally occurring clinical mastitis in periparturient primiparous and multiparous cows on US commercial dairies. J. Dairy Sci. 2017, 100, 6504-6515. [CrossRef]

106. Trimboli, F.; Morittu, V.M.; Di Loria, A.; Minuti, A.; Spina, A.A.; Piccioli-Cappelli, F.; Trevisi, E.; Britti, D.; Lopreiato, V. Effect of Pegbovigrastim on Hematological Profile of Simmental Dairy Cows during the Transition Period. Animals 2019, 9, 841. [CrossRef] [PubMed] 
107. Soliman, C.; Walduck, A.K.; Yuriev, E.; Richards, J.S.; Cywes-Bentley, C.; Pier, G.B.; Ramsland, P.A. Structural basis for antibody targeting of the broadly expressed microbial polysaccharide poly-N-acetylglucosamine. J. Biol. Chem. 2018, 293, 5079-5089. [CrossRef] [PubMed]

108. Domenech, M.; Sempere, J.; de Miguel, S.; Yuste, J. Combination of Antibodies and Antibiotics as a Promising Strategy Against Multidrug-Resistant Pathogens of the Respiratory Tract. Front. Immunol. 2018, 9, 2700. [CrossRef] [PubMed]

109. Navalkele, B.D.; Chopra, T. Bezlotoxumab: An emerging monoclonal antibody therapy for prevention of recurrent Clostridium difficile infection. Biologics 2018, 12, 11-21. [CrossRef]

110. McCrea, K.; Ward, R.; LaRosa, S.P. Removal of Carbapenem-Resistant Enterobacteriaceae (CRE) from blood by heparin-functional hemoperfusion media. PLoS ONE 2014, 9, e114242. [CrossRef]

111. Kang, J.H.; Super, M.; Yung, C.W.; Cooper, R.M.; Domansky, K.; Graveline, A.R.; Mammoto, T.; Berthet, J.B.; Tobin, H.; Cartwright, M.J.; et al. An extracorporeal blood-cleansing device for sepsis therapy. Nat. Med. 2014, 20, 1211-1216. [CrossRef]

112. Amara, N.; Krom, B.P.; Kaufmann, G.F.; Meijler, M.M. Macromolecular inhibition of quorum sensing: Enzymes, antibodies, and beyond. Chem. Rev. 2011, 111, 195-208. [CrossRef]

113. Waters, C.M.; Bassler, B.L. Quorum sensing: Cell-to-cell communication in bacteria. Annu. Rev. Cell Dev. Biol. 2005, 21, 319-346. [CrossRef]

114. Dong, Y.H.; Zhang, L.H. Quorum sensing and quorum-quenching enzymes. J. Microbiol. 2005, 43, 101-109.

115. McDougald, D.; Rice, S.A.; Kjelleberg, S. Bacterial quorum sensing and interference by naturally occurring biomimics. Anal. Bioanal. Chem. 2007, 387, 445-453. [CrossRef]

116. Papenfort, K.; Bassler, B.L. Quorum sensing signal-response systems in Gram-negative bacteria. Nat. Rev. Microbiol. 2016, 14, 576-588. [CrossRef] [PubMed]

117. Bhardwaj, A.K.; Vinothkumar, K.; Rajpara, N. Bacterial quorum sensing inhibitors: Attractive alternatives for control of infectious pathogens showing multiple drug resistance. Recent. Pat. Antiinfect Drug Discov. 2013, 8, 68-83. [CrossRef]

118. Dong, Y.H.; Wang, L.Y.; Zhang, L.H. Quorum-quenching microbial infections: Mechanisms and implications. Philos. Trans. R. Soc. Lond. B Biol. Sci. 2007, 362, 1201-1211. [CrossRef] [PubMed]

119. Aleksić, I.; Šegan, S.; Andrić, F.; Zlatović, M.; Moric, I.; Opsenica, D.M.; Senerovic, L. Long-Chain 4-Aminoquinolines as Quorum Sensing Inhibitors in Serratia marcescens and Pseudomonas aeruginosa. ACS Chem. Biol. 2017, 12, 1425-1434. [CrossRef] [PubMed]

120. Kalia, V.C.; Patel, S.K.S.; Kang, Y.C.; Lee, J.K. Quorum sensing inhibitors as antipathogens: Biotechnological applications. Biotechnol. Adv. 2019, 37, 68-90. [CrossRef] [PubMed]

121. Fetzner, S. Quorum quenching enzymes. J. Biotechnol. 2015, 201, 2-14. [CrossRef]

122. Cech, N.B.; Horswill, A.R. Small-molecule quorum quenchers to prevent Staphylococcus aureus infection. Future Microbiol. 2013, 8, 1511-1514. [CrossRef]

123. Chen, F.; Gao, Y.; Chen, X.; Yu, Z.; Li, X. Quorum quenching enzymes and their application in degrading signal molecules to block quorum sensing-dependent infection. Int. J. Mol. Sci. 2013, 14, 17477-17500. [CrossRef]

124. Goswami, J. Quorum Sensing by Super Bugs and their Resistance to Antibiotics, a Short Review. Glob. J. Pharm. Pharm. Sci. 2017, 3.

125. Brackman, G.; Coenye, T. Inhibition of Quorum Sensing in Staphylococcus spp. Curr. Pharm. Des. 2015, 21, 2101-2108. [CrossRef]

126. Kalia, V.C. Quorum sensing inhibitors: An overview. Biotechnol. Adv. 2013, 31, 224-245. [CrossRef] [PubMed]

127. Ejim, L.; Farha, M.A.; Falconer, S.B.; Wildenhain, J.; Coombes, B.K.; Tyers, M.; Brown, E.D.; Wright, G.D. Combinations of antibiotics and nonantibiotic drugs enhance antimicrobial efficacy. Nat. Chem. Biol. 2011, 7, 348-350. [CrossRef] [PubMed]

128. Kalan, L.; Wright, G.D. Antibiotic adjuvants: Multicomponent anti-infective strategies. Expert Rev. Mol. Med. 2011, 13, e5. [CrossRef] [PubMed]

129. Cottarel, G.; Wierzbowski, J. Combination drugs, an emerging option for antibacterial therapy. Trends Biotechnol. 2007, 25, 547-555. [CrossRef]

130. Conrad, R.S.; Galanos, C. Fatty acid alterations and polymyxin B binding by lipopolysaccharides from Pseudomonas aeruginosa adapted to polymyxin B resistance. Antimicrob. Agents Chemother. 1989, 33, 1724-1728. [CrossRef] 
131. Speer, B.S.; Shoemaker, N.B.; Salyers, A.A. Bacterial resistance to tetracycline: Mechanisms, transfer, and clinical significance. Clin. Microbiol. Rev. 1992, 5, 387-399. [CrossRef]

132. Van Bambeke, F.; Pagès, J.M.; Lee, V.J. Inhibitors of bacterial efflux pumps as adjuvants in antibiotic treatments and diagnostic tools for detection of resistance by efflux. Recent. Pat. Antiinfect. Drug Discov. 2006, 1, 157-175. [CrossRef]

133. Kolodkin-Gal, I.; Romero, D.; Cao, S.; Clardy, J.; Kolter, R.; Losick, R. D-amino acids trigger biofilm disassembly. Science 2010, 328, 627-629. [CrossRef]

134. Pérez, J.M.; Calderón, I.L.; Arenas, F.A.; Fuentes, D.E.; Pradenas, G.A.; Fuentes, E.L.; Sandoval, J.M.; Castro, M.E.; Elías, A.O.; Vásquez, C.C. Bacterial toxicity of potassium tellurite: Unveiling an ancient enigma. PLoS ONE 2007, 2, e211. [CrossRef]

135. Calderón, I.L.; Elías, A.O.; Fuentes, E.L.; Pradenas, G.A.; Castro, M.E.; Arenas, F.A.; Pérez, J.M.; Vásquez, C.C. Tellurite-mediated disabling of [4Fe-4S] clusters of Escherichia coli dehydratases. Microbiology 2009, 155, 1840-1846. [CrossRef]

136. Castro, M.E.; Molina, R.C.; Díaz, W.A.; Pradenas, G.A.; Vásquez, C.C. Expression of Aeromonas caviae ST pyruvate dehydrogenase complex components mediate tellurite resistance in Escherichia coli. Biochem. Biophys. Res. Commun. 2009, 380, 148-152. [CrossRef]

137. Turner, R.J.; Aharonowitz, Y.; Weiner, J.H.; Taylor, D.E. Glutathione is a target in tellurite toxicity and is protected by tellurite resistance determinants in Escherichia coli. Can. J. Microbiol. 2001, 47, 33-40. [CrossRef]

138. Pérez, J.M.; Arenas, F.A.; Pradenas, G.A.; Sandoval, J.M.; Vásquez, C.C. Escherichia coli YqhD exhibits aldehyde reductase activity and protects from the harmful effect of lipid peroxidation-derived aldehydes. J. Biol. Chem. 2008, 283, 7346-7353. [CrossRef]

139. Annunziato, G. Strategies to Overcome Antimicrobial Resistance (AMR) Making Use of Non-Essential Target Inhibitors: A Review. Int. J. Mol. Sci. 2019, 20, 5844. [CrossRef]

140. Douafer, H.; Andrieu, V.; Phanstiel, O.t.; Brunel, J.M. Antibiotic Adjuvants: Make Antibiotics Great Again! J. Med. Chem. 2019, 62, 8665-8681. [CrossRef]

141. Chan, W.Y.; Khazandi, M.; Hickey, E.E.; Page, S.W.; Trott, D.J.; Hill, P.B. In vitro antimicrobial activity of seven adjuvants against common pathogens associated with canine otitis externa. Vet. Dermatol. 2019, 30, 133. [CrossRef]

142. Bakken, J.S.; Borody, T.; Brandt, L.J.; Brill, J.V.; Demarco, D.C.; Franzos, M.A.; Kelly, C.; Khoruts, A.; Louie, T.; Martinelli, L.P.; et al. Treating Clostridium difficile infection with fecal microbiota transplantation. Clin. Gastroenterol. Hepatol. 2011, 9, 1044-1049. [CrossRef]

143. Smits, L.P.; Bouter, K.E.; de Vos, W.M.; Borody, T.J.; Nieuwdorp, M. Therapeutic potential of fecal microbiota transplantation. Gastroenterology 2013, 145, 946-953. [CrossRef]

144. DePeters, E.J.; George, L.W. Rumen transfaunation. Immunol. Lett. 2014, 162, 69-76. [CrossRef]

145. Eiseman, B.; Silen, W.; Bascom, G.S.; Kauvar, A.J. Fecal enema as an adjunct in the treatment of pseudomembranous enterocolitis. Surgery 1958, 44, 854-859.

146. Zhang, F.; Luo, W.; Shi, Y.; Fan, Z.; Ji, G. Should we standardize the 1700-year-old fecal microbiota transplantation? Am. J. Gastroenterol. 2012. [CrossRef]

147. Wortelboer, K.; Nieuwdorp, M.; Herrema, H. Fecal microbiota transplantation beyond Clostridioides difficile infections. EBioMedicine 2019, 44, 716-729. [CrossRef]

148. Khoruts, A.; Staley, C.; Sadowsky, M.J. Faecal microbiota transplantation for Clostridioides difficile: Mechanisms and pharmacology. Nat. Rev. Gastroenterol. Hepatol. 2020. [CrossRef]

149. Gopinath, P.M.; Narchonai, G.; Dhanasekaran, D.; Ranjani, A.; Thajuddin, N. Mycosynthesis, characterization and antibacterial properties of AgNPs against multidrug resistant (MDR) bacterial pathogens of female infertility cases. Asian J. Pharm. Sci. 2015, 10, 138-145. [CrossRef]

150. Ingle, A.P.; Duran, N.; Rai, M. Bioactivity, mechanism of action, and cytotoxicity of copper-based nanoparticles: A review. Appl. Microbiol. Biotechnol. 2014, 98, 1001-1009. [CrossRef]

151. Li, X.; Robinson, S.M.; Gupta, A.; Saha, K.; Jiang, Z.; Moyano, D.F.; Sahar, A.; Riley, M.A.; Rotello, V.M. Functional gold nanoparticles as potent antimicrobial agents against multi-drug-resistant bacteria. ACS Nano 2014, 8, 10682-10686. [CrossRef]

152. Ibrahem, K.H.; Salman, J.A.S.; Ali, F.A. Effect of titanium nanoparticles biosynthesis by Lactobacillus crispatus on urease, hemolysin \& biofilm forming by some bacteria causing recurrent UTI in Iraqi women. Eur. Sci. J. 2014, 10. 
153. Vincent, M.G.; John, N.P.; Narayanan, P.M.; Vani, C.; Murugan, S. In vitro study on the efficacy of zinc oxide and titanium dioxide nanoparticles against metallo beta-lactamase and biofilm producing Pseudomonas aeruginosa. J. Appl. Pharm. Sci. 2014, 4, 41-46. [CrossRef]

154. Malka, E.; Perelshtein, I.; Lipovsky, A.; Shalom, Y.; Naparstek, L.; Perkas, N.; Patick, T.; Lubart, R.; Nitzan, Y.; Banin, E.; et al. Eradication of multi-drug resistant bacteria by a novel Zn-doped CuO nanocomposite. Small 2013, 9, 4069-4076. [CrossRef]

155. Huang, Z.; Zheng, X.; Yan, D.; Yin, G.; Liao, X.; Kang, Y.; Yao, Y.; Huang, D.; Hao, B. Toxicological effect of $\mathrm{ZnO}$ nanoparticles based on bacteria. Langmuir 2008, 24, 4140-4144. [CrossRef]

156. Ansari, M.A.; Khan, H.M.; Khan, A.A.; Cameotra, S.S.; Saquib, Q.; Musarrat, J. Interaction of $\mathrm{Al}(2) \mathrm{O}(3)$ nanoparticles with Escherichia coli and their cell envelope biomolecules. J. Appl. Microbiol. 2014, 116, 772-783. [CrossRef] [PubMed]

157. Fernandez-Moure, J.S.; Evangelopoulos, M.; Colvill, K.; Van Eps, J.L.; Tasciotti, E. Nanoantibiotics: A new paradigm for the treatment of surgical infection. Nanomedicine (Lond.) 2017, 12, 1319-1334. [CrossRef] [PubMed]

158. Muzammil, S.; Hayat, S.; Fakhar, E.A.M.; Aslam, B.; Siddique, M.H.; Nisar, M.A.; Saqalein, M.; Atif, M.; Sarwar, A.; Khurshid, A.; et al. Nanoantibiotics: Future nanotechnologies to combat antibiotic resistance. Front. Biosci. (Elite Ed.) 2018, 10, 352-374. [CrossRef] [PubMed]

159. Witte, M.B.; Barbul, A. Role of nitric oxide in wound repair. Am. J. Surg. 2002, 183, 406-412. [CrossRef]

160. Friedman, A.; Friedman, J. New biomaterials for the sustained release of nitric oxide: Past, present and future. Expert Opin. Drug Deliv. 2009, 6, 1113-1122. [CrossRef] [PubMed]

161. Kafshgari, M.H.; Cavallaro, A.; Delalat, B.; Harding, F.J.; McInnes, S.J.; Mäkilä, E.; Salonen, J.; Vasilev, K.; Voelcker, N.H. Nitric oxide-releasing porous silicon nanoparticles. Nanoscale Res. Lett. 2014, 9, 333. [CrossRef]

162. Kim, S.; Lee, D.G. PMAP-23 triggers cell death by nitric oxide-induced redox imbalance in Escherichia coli. Biochim. Biophys. Acta Gen. Subj. 2019, 1863, 1187-1195. [CrossRef] [PubMed]

163. Bang, C.S.; Kinnunen, A.; Karlsson, M.; Önnberg, A.; Söderquist, B.; Persson, K. The antibacterial effect of nitric oxide against ESBL-producing uropathogenic E. coli is improved by combination with miconazole and polymyxin B nonapeptide. BMC Microbiol. 2014, 14, 65. [CrossRef]

164. Brisbois, E.J.; Bayliss, J.; Wu, J.; Major, T.C.; Xi, C.; Wang, S.C.; Bartlett, R.H.; Handa, H.; Meyerhoff, M.E. Optimized polymeric film-based nitric oxide delivery inhibits bacterial growth in a mouse burn wound model. Acta Biomater. 2014, 10, 4136-4142. [CrossRef]

165. Kadam, S.; Shai, S.; Shahane, A.; Kaushik, K.S. Recent Advances in Non-Conventional Antimicrobial Approaches for Chronic Wound Biofilms: Have We Found the 'Chink in the Armor'? Biomedicines 2019, 7, 35. [CrossRef]

166. Panacek, A.; Kvítek, L.; Prucek, R.; Kolar, M.; Vecerova, R.; Pizúrova, N.; Sharma, V.K.; Nevecna, T.; Zboril, R. Silver colloid nanoparticles: Synthesis, characterization, and their antibacterial activity. J. Phys. Chem. B 2006, 110, 16248-16253. [CrossRef] [PubMed]

167. Abdel-Aziz, M.M.; Elella, M.H.A.; Mohamed, R.R. Green synthesis of quaternized chitosan/silver nanocomposites for targeting mycobacterium tuberculosis and lung carcinoma cells (A-549). Int. J. Biol. Macromol. 2020, 142, 244-253. [CrossRef] [PubMed]

168. Saeb, A.T.; Alshammari, A.S.; Al-Brahim,H.; Al-Rubeaan, K.A. Production of silver nanoparticles with strong and stable antimicrobial activity against highly pathogenic and multidrug resistant bacteria. Sci. World J. 2014, 2014, 704-708. [CrossRef] [PubMed]

169. Singh, K.; Panghal, M.; Kadyan, S.; Chaudhary, U.; Yadav, J.P. Green silver nanoparticles of Phyllanthus amarus: As an antibacterial agent against multi drug resistant clinical isolates of Pseudomonas aeruginosa. J. Nanobiotechnol. 2014, 12, 40. [CrossRef] [PubMed]

170. Manzoor-ul-Haq, V.R.; Singh, D.; Singh, A.K.; Ninganagouda, S.; Hiremath, A.J. Dried Mushroom Agaricus bisporus mediated synthesis of silver nanoparticles from Bandipora District (Jammu and Kashmir) and their efficacy against Methicillin Resistant Staphylococcus aureus (MRSA) strains. Nanosci. Nanotechnol. Int. J. 2015, 5, 1-8.

171. Behera, S.; Nayak, P.L. In vitro Antibacterial Activity of Green Synthesized Silver Nanoparticles Using Jamun Extract Against Multiple Drug Resistant Bacteria. World J. Nano Sci. Technol. 2013, 2, 62-65. [CrossRef] 
172. Singh, K.; Panghal, M.; Kadyan, S.; Chaudhary, U.; Yadav, J.P. Antibacterial Activity of Synthesized Silver Nanoparticles from Tinospora cordifolia against Multi Drug Resistant Strains of Pseudomonas aeruginosa Isolated from Burn Patients. J. Nanomed. Nanotechnol. 2014, 5. [CrossRef]

173. Chandrakanth, R.K.; Ashajyothi, C.; Oli, A.K.; Prabhurajeshwar, C. Potential Bactericidal Effect of Silver Nanoparticles Synthesised from Enterococcus Species. Orient. J. Chem. 2014, 30, 1253-1262.

174. Lara, H.H.; Ayala-Nunez, N.V.; Ixtepan-Turrent, L.; Rodríguez-Padilla, C. Bactericidal effect of silver nanoparticles against multidrug-resistant bacteria. World J. Microbiol. Biotechnol. 2010, 26, 615-621. [CrossRef]

175. Ingle, A.; Gade, A.; Pierrat, S.; Sonnichsen, C.; Rai, M. Mycosynthesis of Silver Nanoparticles Using the Fungus Fusarium acuminatum and its Activity Against Some Human Pathogenic Bacteria. Curr. Nanosci. 2008, 4, 141-144. [CrossRef]

176. Prabakar, K.; Sivalingam, P.; Mohamed Rabeek, S.I.; Muthuselvam, M.; Devarajan, N.; Arjunan, A.; Karthick, R.; Suresh, M.M.; Wembonyama, J.P. Evaluation of antibacterial efficacy of phyto fabricated silver nanoparticles using Mukia scabrella (Musumusukkai) against drug resistance nosocomial gram negative bacterial pathogens. Colloids Surf. B Biointerfaces 2013, 104, 282-288. [CrossRef] [PubMed]

177. John, S.N. Evaluation of antibacteria lefficacy of phyto-fabricated gold nanoparticles using Bacopa monnieri plant extract. Indian J. Adv. Chem. Sci. 2013, 1, 94-98.

178. Kunkalekar, R.K.; Naik, M.M.; Dubey, S.K.; Salker, A.V. Antibacterial activity of silver-dopedmanganese dioxide nanoparticles onmultidrug-resistant bacteria. J. Chem. Technol. Biotechnol. 2013, 88, 873-877. [CrossRef]

179. Kalantar, E.; Kabir, K.; Gharibi, F.; Hatami, S.; Maleki, A. Effect and Properties of Surface-Modified Copper Doped ZnO Nanoparticles (Cu:ZnO NPs) on Killing Curves of Bacterial Pathogens. J. Med. Bacteriol. 2013, 2, 20-26.

180. Bhande, R.M.; Khobragade, C.N.; Mane, R.S.; Bhande, S. Enhanced synergism of antibiotics with zinc oxide nanoparticles against extended spectrum b-lactamase producers implicated in urinary tract infections. J. Nanopart Res. 2013, 15, 1-13. [CrossRef]

181. Roy, A.S.; Parveen, A.; Koppalkar, A.R.; Prasad, M.V.N.A. Effect of Nano - Titanium Dioxide with Different Antibiotics against Methicillin-Resistant Staphylococcus Aureus. J. Biomater. Nanobiotechnol. 2010, 1, 37-41. [CrossRef]

182. Brown, A.N.; Smith, K.; Samuels, T.A.; Lu, J.; Obare, S.O.; Scott, M.E. Nanoparticles functionalized with ampicillin destroy multiple-antibiotic-resistant isolates of Pseudomonas aeruginosa and Enterobacter aerogenes and methicillin-resistant Staphylococcus aureus. Appl. Environ. Microbiol. 2012, 78, 2768-2774. [CrossRef]

183. Naqvi, S.Z.; Kiran, U.; Ali, M.I.; Jamal, A.; Hameed, A.; Ahmed, S.; Ali, N. Combined efficacy of biologically synthesized silver nanoparticles and different antibiotics against multidrug-resistant bacteria. Int. J. Nanomed. 2013, 8, 3187-3195. [CrossRef]

184. Burt, S. Essential oils: Their antibacterial properties and potential applications in foods-a review. Int. J. Food Microbiol. 2004, 94, 223-253. [CrossRef]

185. Cowan, M.M. Plant products as antimicrobial agents. Clin. Microbiol. Rev. 1999, 12, 564-582. [CrossRef]

186. Savoia, D. Plant-derived antimicrobial compounds: Alternatives to antibiotics. Future Microbiol. 2012, 7, 979-990. [CrossRef] [PubMed]

187. Veras, H.N.; Rodrigues, F.F.; Colares, A.V.; Menezes, I.R.; Coutinho, H.D.; Botelho, M.A.; Costa, J.G. Synergistic antibiotic activity of volatile compounds from the essential oil of Lippia sidoides and thymol. Fitoterapia 2012, 83, 508-512. [CrossRef] [PubMed]

188. Raut, J.S.; Karuppayil, S.M. A status review on the medicinal properties of essential oils. Ind. Crops Prod. 2014, 62, 250-264. [CrossRef]

189. Aleksic Sabo, V.; Knezevic, P. Antimicrobial activity of Eucalyptus camaldulensis Dehn. plant extracts and essential oils: A review. Ind. Crops Prod. 2019, 132, 413-429. [CrossRef]

190. Wińska, K.; Mączka, W.; Łyczko, J.; Grabarczyk, M.; Czubaszek, A.; Szumny, A. Essential Oils as Antimicrobial Agents-Myth or Real Alternative? Molecules 2019, 24, 2130. [CrossRef]

191. Mitscher, L.A.; Drake, S.; Gollapudi, S.R.; Okwute, S.K. A modern look at folkloric use of anti-infective agents. J. Nat. Prod. 1987, 50, 1025-1040. [CrossRef] 
192. Wang, Y.; Hong, J.; Liu, X.; Yang, H.; Liu, R.; Wu, J.; Wang, A.; Lin, D.; Lai, R. Snake cathelicidin from Bungarus fasciatus is a potent peptide antibiotics. PLoS ONE 2008, 3, e3217. [CrossRef]

193. Flores-Villaseñor, H.; Canizalez-Román, A.; Reyes-Lopez, M.; Nazmi, K.; de la Garza, M.; Zazueta-Beltrán, J.; León-Sicairos, N.; Bolscher, J.G. Bactericidal effect of bovine lactoferrin, LFcin, LFampin and LFchimera on antibiotic-resistant Staphylococcus aureus and Escherichia coli. Biometals 2010, 23, 569-578. [CrossRef]

194. Daniel, R. The soil metagenome-A rich resource for the discovery of novel natural products. Curr. Opin. Biotechnol. 2004, 15, 199-204. [CrossRef]

195. Mokoena, M.P. Lactic Acid Bacteria and Their Bacteriocins: Classification, Biosynthesis and Applications against Uropathogens: A Mini-Review. Molecules 2017, 22, 1255. [CrossRef] [PubMed]

196. Tsilingiri, K.; Barbosa, T.; Penna, G.; Caprioli, F.; Sonzogni, A.; Viale, G.; Rescigno, M. Probiotic and postbiotic activity in health and disease: Comparison on a novel polarised ex-vivo organ culture model. Gut 2012, 61, 1007-1015. [CrossRef] [PubMed]

197. Aguilar-Toalá, J.E.; Garcia-Varela, R.; Garcia,H.S.; Mata-Haro, V.; González-Córdova, A.F.; Vallejo-Cordoba, B.; Hernández-Mendoza, A. Postbiotics: An evolving term within the functional foods field. Trends Food Sci. Technol. 2018, 75, 105-114. [CrossRef]

198. Uyeno, Y.; Shigemori, S.; Shimosato, T. Effect of Probiotics/Prebiotics on Cattle Health and Productivity. Microbes Environ. 2015, 30, 126-132. [CrossRef] [PubMed]

199. Wegh, C.A.M.; Geerlings, S.Y.; Knol, J.; Roeselers, G.; Belzer, C. Postbiotics and Their Potential Applications in Early Life Nutrition and Beyond. Int. J. Mol. Sci. 2019, 20, 4673. [CrossRef] [PubMed]

200. Tyagi, A.K.; Malik, A. Antimicrobial potential and chemical composition of Mentha piperita oil in liquid and vapour phase against food spoiling microorganisms. Food Control 2011, 22, 1707-1714. [CrossRef]

201. Mahboubi, M.; Haghi, G. Antimicrobial activity and chemical composition of Mentha pulegium L. essential oil. J. Ethnopharmacol. 2008, 119, 325-327. [CrossRef] [PubMed]

202. Ahmad, A.; Khan, A.; Samber, N.; Manzoor, N. Antimicrobial activity of Mentha piperita essential oil in combination with silver ions. Synergy 2014, 1, 92-98. [CrossRef]

203. Hussain, A.I.; Anwar, F.; Hussain Sherazi, S.T.; Przybylski, R. Chemical composition, antioxidant and antimicrobial activities of basil (Ocimum basilicum) essential oils depends on seasonal variations. Food Chem. 2008, 108, 986-995. [CrossRef]

204. Opalchenova, G.; Obreshkova, D. Comparative studies on the activity of basil-an essential oil from Ocimum basilicum L.-against multidrug resistant clinical isolates of the genera Staphylococcus, Enterococcus and Pseudomonas by using different test methods. J. Microbiol. Methods 2003, 54, 105-110. [CrossRef]

205. Koga, T.; Hirota, N.; Takumi, K. Bactericidal activities of essential oils of basil and sage against a range of bacteria and the effect of these essential oils on Vibrio parahaemolyticus. Microbiol. Res. 1999, 154, 267-273. [CrossRef]

206. Sarikurkcu, C.; Zengin, G.; Oskay, M.; Uysal, S.; Ceylan, R.; Aktumsek, A. Composition, antioxidant, antimicrobial and enzyme inhibition activities of two Origanum vulgare subspecies (subsp. vulgare and subsp. hirtum) essential oils. Ind. Crops Prod. 2015, 70, 178-184. [CrossRef]

207. Gutierrez, J.; Barry-Ryan, C.; Bourke, P. The antimicrobial efficacy of plant essential oil combinations and interactions with food ingredients. Int. J. Food Microbiol. 2008, 124, 91-97. [CrossRef]

208. Jiang, Y.; Wu, N.; Fu, Y.-J.; Wang, W.; Luo, M.; Zhao, C.-J.; Zu, Y.-G.; Liu, X.-L. Chemical composition and antimicrobial activity of the essential oil of Rosemary. Environ. Toxicol. Pharmacol. 2011, 32, 63-68. [CrossRef]

209. Ojeda-Sana, A.M.; van Baren, C.M.; Elechosa, M.A.; Juárez, M.A.; Moreno, S. New insights into antibacterial and antioxidant activities of rosemary essential oils and their main components. Food Control 2013, 31, 189-195. [CrossRef]

210. Lemos, M.F.; Lemos, M.F.; Pacheco, H.P.; Endringer, D.C.; Scherer, R. Seasonality modifies rosemary's composition and biological activity. Ind. Crops Prod. 2015, 70, 41-47. [CrossRef]

211. Barreto, H.M.; Silva Filho, E.C.; Lima, E.d.O.; Coutinho, H.D.M.; Morais-Braga, M.F.B.; Tavares, C.C.A.; Tintino, S.R.; Rego, J.V.; de Abreu, A.P.L.; Lustosa, M.d.C.G.; et al. Chemical composition and possible use as adjuvant of the antibiotic therapy of the essential oil of Rosmarinus officinalis L. Ind. Crops Prod. 2014, 59, 290-294. [CrossRef]

212. Parmeciano Di Noto, G.; Molina, M.C.; Quiroga, C. Insights Into Non-coding RNAs as Novel Antimicrobial Drugs. Front Genet. 2019, 10, 57. [CrossRef] 
213. Lipsitch, M.; Siber, G.R. How Can Vaccines Contribute to Solving the Antimicrobial Resistance Problem? mBio 2016, 7. [CrossRef]

214. Kumar, S.G.; Adithan, C.; Harish, B.N.; Sujatha, S.; Roy, G.; Malini, A. Antimicrobial resistance in India: A review. J. Nat. Sci. Biol. Med. 2013, 4, 286-291. [CrossRef]

215. Metz, M.; Shlaes, D.M. Eight more ways to deal with antibiotic resistance. Antimicrob. Agents Chemother. 2014, 58, 4253-4256. [CrossRef]

216. Rubio-Cosials, A.; Schulz, E.C.; Lambertsen, L.; Smyshlyaev, G.; Rojas-Cordova, C.; Forslund, K.; Karaca, E.; Bebel, A.; Bork, P.; Barabas, O. Transposase-DNA Complex Structures Reveal Mechanisms for Conjugative Transposition of Antibiotic Resistance. Cell 2018, 173, 208-220.e220. [CrossRef]

(C) 2020 by the authors. Licensee MDPI, Basel, Switzerland. This article is an open access article distributed under the terms and conditions of the Creative Commons Attribution (CC BY) license (http://creativecommons.org/licenses/by/4.0/). 